COLLEGE OF AGRICULTURE

AGRICULTURAL EXPERIMENT STATION

BERKELEY, CALIFORNIA

\title{
THE BLACK SCALE
}

BY H. J. QUAYLE

Assisted By E. W. RUST

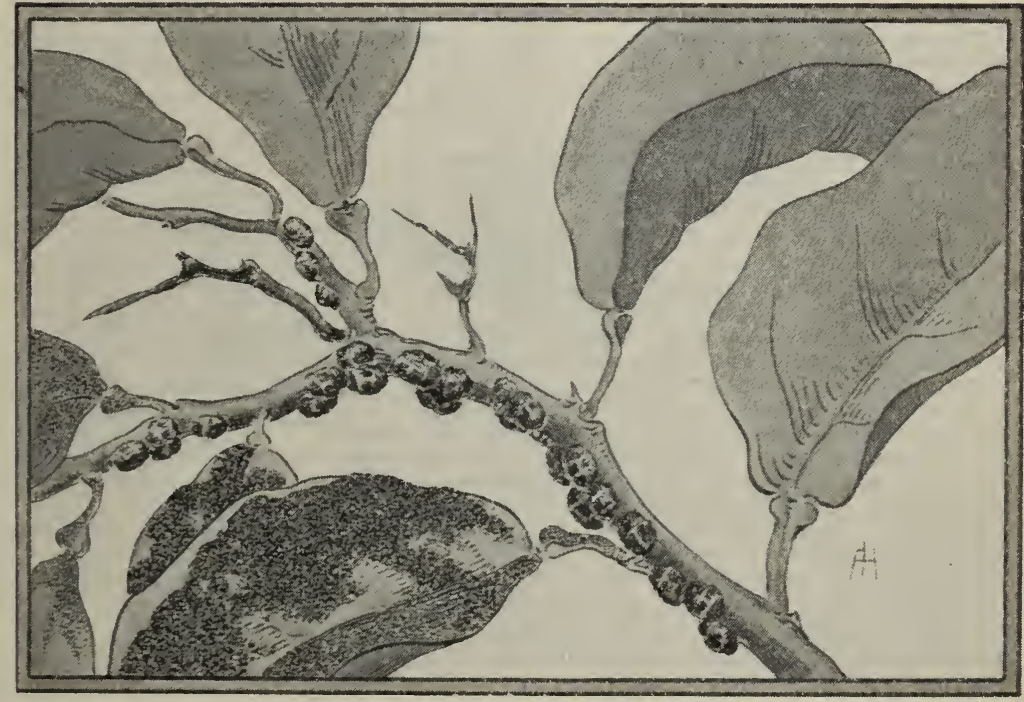

BULLETIN No. 223.

BERKELEY, CAL., JULY, 1911

S A C R A E N T O

II. W. SHANNON - - - - SUPERINTENDENT STATE PRINTING 


\section{EXPERIMENT STATION STAFF.}

E. J. WICkson, M.A., Director and Horticulturist.

E. W. Hilgard, Ph.D., LL.D., Chemist (Emeritus).

W. A. Setchell, Ph.D., Botanist.

Leroy Anderson, Ph.D., Dairy Industry and Superintendent University Farm Schools.

M. E. JAFFA, M.S., Nutrition Expert.

R. H. Loughridge, Ph.D., Soil Chemist and Physicist (Emeritus).

C. W. WooDWorTH, M.S., Entomologist.

RalPh E. Smith, B.S., Plant Pathologist and Superintendent of Southern California Pathological Laboratory and Experiment Station.

G. W. ShAw, M.A., Ph.D., Experimental Agronomist and Agricultural Technologist, in charge of Cereal Stations.

E. W. MAJor, B.Agr., Animal Industry.

B. A. EtcheverRx, B.S., Irrigation Expert.

F. T. BIOLETTI, B.S., Viticulturist.

W. T. Clarke, B.S., Assistant Horticulturist and Superintendent of University Extension in Agriculture.

JoHN S. Burd, B.S., Chemist, in charge of Fertilizer Control.

J. E. CoIT, Ph.D., Assistant Pomologist, Plant Disease Laboratory, Whittier.

George E. Colbr, M.S., Chemist (Fruits, Waters, and Insecticides), in charge of Chemical Laboratory.

H. J. QUAYLE, M.S., Assistant Entomologist, Plant Disease Laboratory, Whittier.

H. M. HALL, Ph.D., Assistant Botanist.

C. M. Haring, D.V.M., Assistant Veterinarian and Bacteriologist.

E. B. BABCOCK, B.S., Assistant Agricultural Education.

W. B. Herms, M.A., Assistant Entomologist.

J. H. NoRTon, M.S., Assistant Chemist, in charge of Citrus Experiment Station, Riverside.

W. T. Horne, B.S., Assistant Plant Pathologist.

C. B. LIPMAN, Ph.D., Soil Chemist and Bacteriologist.

R. E. MANSELL, Assistant Horticulturist, in charge of Central Station grounds.

A. J. Gaumnitz, Assistant Agronomist, University Farm, Davis.

N. D. InghaM, B.S., Assistant in Sylviculture, Santa Monica.

T. F. Hunt, B.S., Assistant Plant Pathologist.

P. L. MCCrearx, B.S., Chemist in Fertilizer Control.

E. H. HagemanN, Assistant in Dairying, Davis.

R. M. Roberts, Farm Manager, University Farm, Davis.

B. S. Brown, B.S.A., Assistant Horticulturist, University Farm, Davis.

J. I. Thompson, B.S., Assistant Animal Industry, Davis.

How ARD PHILlips, B.S., Assistant Animal Industry, Davis.

J. C. BRIDWELL, B.S., Assistant Entomologist.

C. H. MCCharles, M.S., Assistant Agricultural Chemical Laboratory.

E. H. SMITH, M.S., Assistant Plant Pathologist.

C. O. Smith, M.S., Assistant Plant Pathologist, Plant Disease Laboratory, Whittier.

F. E. Johnson, B.L., M.S., Assistant Soil Chemist.

B. A. Madson, B.S.A., Assistant Experimental Agronomist.

WALTER E. PACKARD, M.S., Field Assistant Imperial Valley Investigation, El Centro.

P. L. Hibbard, B.S., Assistant Fertilizer Control Laboratory.

L. M. DAvis, B.S., Assistant in Dairy Husbandry, University Farm, Davis.

S. S. Rogers, B.S., Assistant Plant Pathologist, Plant Disease Laboratory, Whittier.

L. BonNeT, Assistant Viticulturist.

H. A. Ruene, B.S.A., Assistant in Dairy Husbandry, University Farm, Davis.

F. C. H. Flossfeder, Assistant in Viticulture, University Farm, Davis.

S. D. Wilkins, Assistant in Poultry Husbandry, University Farm, Davis.

C. L. RoAdHouse, D.V.M., Assistant in Veterinary Science.

F. M. HAXES, D.V.M., Assistant Veterinarian.

F. L. YEAW, B.S., Assistant Plant Pathologist, University Farm, Davis.

M. E. STover, B.S., Assistant in Agricultural Chemical Laboratory.

W. H. VoLCK, Field Assistant in Entomology, Watsonville.

E. L. Morris, Field Assistant in Entomology, San Jose.

E. E. Thomas, B.S., Assistant Chemist, Plant Disease Laboratory, Whittier.

A. B. SHAw, B.S., Assistant in Entomology.

G. P. GRAX, M.S., Chemist in Insecticides.

H. D. Young, B.S., Assistant in Agricultural Chemistry, Plant Disease Laboratory, Whittier.

A. R. TrLor, B.S., Assistant in Plant Pathology, Plant Disease Laboratory, Whittier.

E. W. Rust, A. B., Assistant in Entomology, Plant Disease Laboratory, Whittier.

L. T. SHARP, B.S., Assistant in Soils.

W. W. CRuess, B.S., Assistant in Zymology.

J. F. MitchelL, D.V.M., Assistant in Veterinary Laboratory.

J. C. Roper, Patron, University Forestry Station, Chico.

E. C. Miller, Foreman, Forestry Station, Chico.

D. L. BunNell, Secretary to Director. 


\section{CONTENTS.}

PAGE.

HISTORICAL _-_-

DISTRIBUTION _---_--_-_-_-_- 151

ECONOMIC IMPORTANCE -_-_-_-_-_-_-_- 153

NATURE OF INJURY_-_-_-_- 154

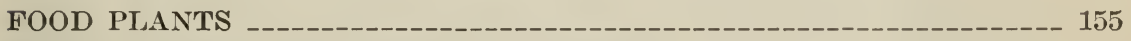

DESCRIPTION-LIFE HISTORY-HABITS --_-_-_-_-__-_-_-_-_ 157

THE EgG --_-_-_-_-_- 157

Description - -

Incubation period -

Number - - -

Percentage that hatch -_-_-_-_-_-_-_-_-_-_-_-_-_-_-_-_-_-_-_- 157

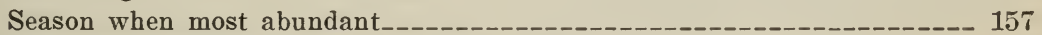

Relation of weight of eggs to weight of body

Hatching records -

The ACtive LARva____-

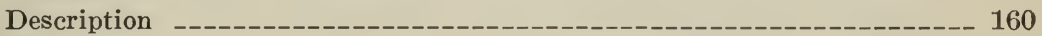

Emergence - - 160

Locomotion - -

Rate of travel over smooth surfaces

Rate of travel over sand and orchard soil__-__-_-_-_-_-_-_-_-_-_- 163

Other factors in the spread of the young scale_-_-_-_-_-_-_-_- 164

Length of life without food

Experiments on the effect of temperature

Effects of light_-_-_-_-_-_-_-_-_-_- 166

Where the young settle_-_-_-_-_-_-_-_-_-_-_-_-_-_-_-_-_-_-_ 167

Proportion of young becoming fixed._-_-_-_-_-_-_- 168

The Fixed YounG

Development before first molt_-_-_-_-_-_-_-_-_- 168

The first molt_-_-_-_-_-_-_-_-_-_-_-_-_-_-_-_-_-_-_-_-_-_- 169

Development between first and second molts____-_-_-_-_-_-_-_-_-_-_- 169

The second molt of the female

Process of molting

Effects of temperature

Honeydew and fungus growth

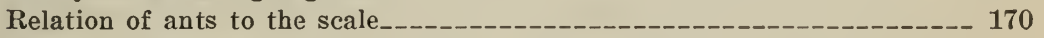

Movement after settling-_-_-_-_-_-_-_-_-_-_-_- 170

'The Adult Female_-__-

Description -

Oviposition -_-_-_-_-_-_-_- 172

The Development of THe MaLe_-_-_-_- 173

The second stage male_-_-_-_-_-_-_ 173

The male puparium

The propupa -

The pupa --_-_-_-_-_- 175

The adult male

SEASONAL History -

Number of generations_-_-_-_-_-_- 176

Mortality at different seasons__-_-_-_-_-_-_-_-_-_-_-_-_-_-_-_-- 177

Annual progeny of a single scale__-_-_-_-_-_-_-_-_-_-_-_-_-_-_ 178 
CONTENTS.

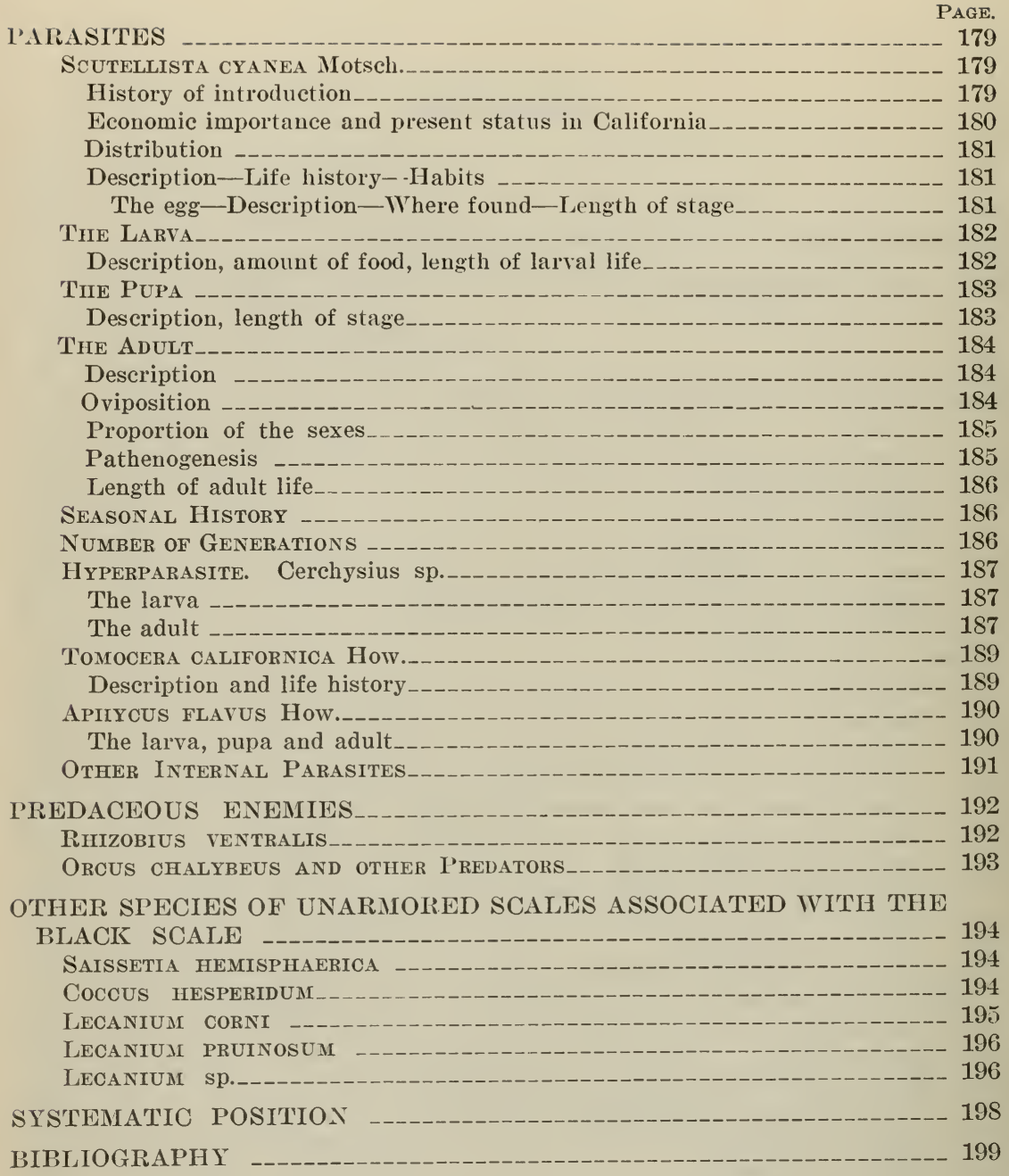




\section{THE BLACK SCALE.}

SAISSETIA OLEE Bern.

By H. J. QuaYle.

Assisted by E. IV. Rust.

HISTORICAL.

The Black Scale, Saissetia olece Bern, is widely distributed over most of the countries of the world, and has been known as a pest of the olive in the Old World nearly as far back as our entomological records go. It was first described by a Frenchman named Bernard* from specimens taken on olive in 1782. It was given the specific name olece from the host plant on which it was originally found. Articles have since appeared on this insect in various countries, so that the list now totals more than 100 papers.

Just when it was introduced into California, or from what country, doesn't appear to be established. The first complete account of its occurrence here is given in Comstock's report for 1880. It had been in the State, however, many years previous to that time. By 1880 it was well established in various parts of the State, and found infesting a wide range of food plants ; but it was at that time, as now, a particularly serious enemy to citrus trees. It was given the common name of "Black Scale of California." Since this was the first reference to this scale in the literature of this country, and because of the common name applied, it appears that it was unknown in the United States, at that time, outside of California.

\section{DISTRIBUTION.}

The following localities give the present distribution of $S$. olece over the world: Aldabia, Mauritius, Europe, New Zealand, Australia, China, Japan, Java, Africa, Ceylon, Brazil, W. Indies, Mexico, France, Italy, Spain, Massachusetts, South Carolina, Ohio, Florida, and California.

In California it occurs to a greater or less extent in practically all of the counties. As a pest it is limited to the citrus belt of southern California, the different deciduous trees in the coast counties about San Francisco Bay, and to some extent on olive trees of the interior valleys. It occurs throughout the valleys on oleander and olive in varying degrees, but is not often serious enough to warrant treatment. In certain places in the lower Sacramento Valley it has become abundant enough on the olive to necessitate spraying.

In the citrus area of southern California, the black scale is the most

*1 Mem. d'Hist. Nat. Acad., Marseilles, p. 108 (1782). 


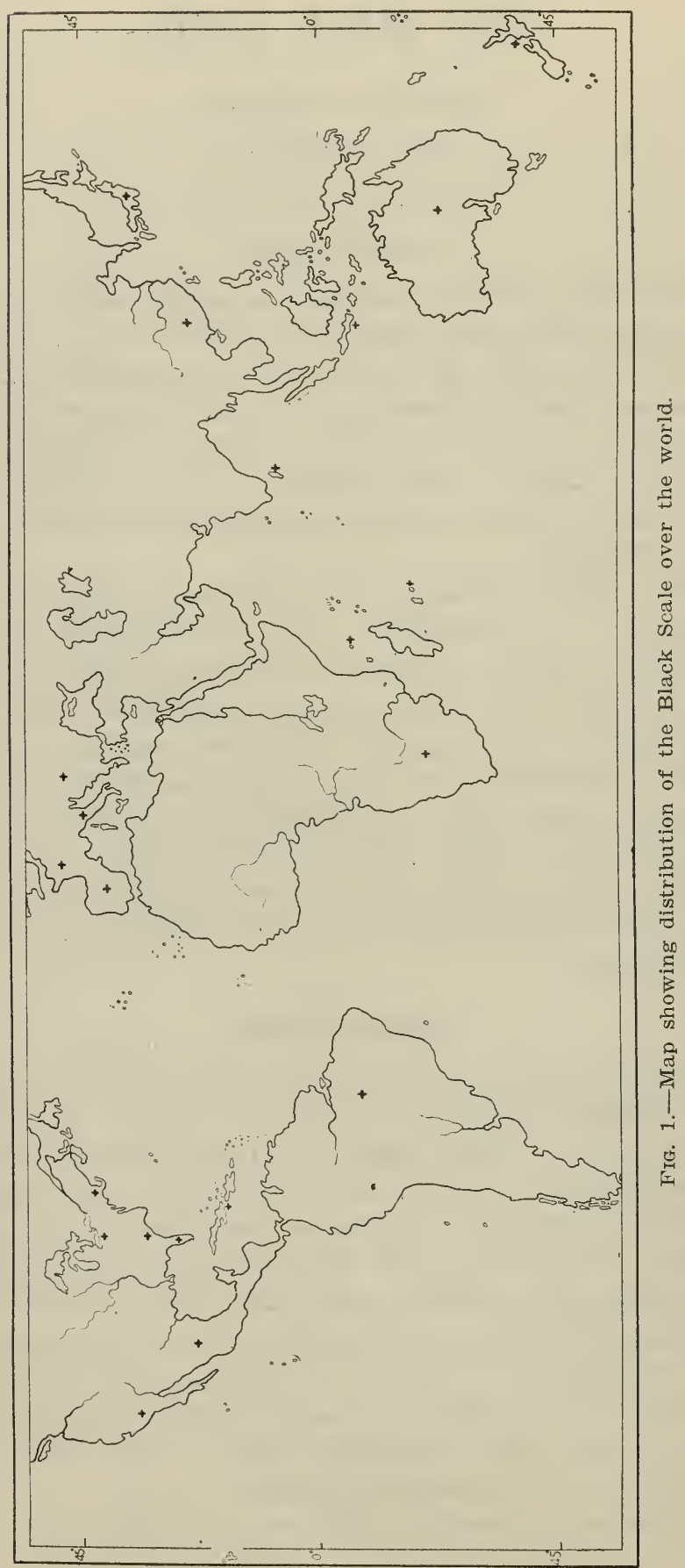


widely distributed of all the scale pests. It occurs in all of the counties from Santa Barbara to San Diego. It is less abundant in the interior counties of Riverside and San Bernardino; but even here in some sec-

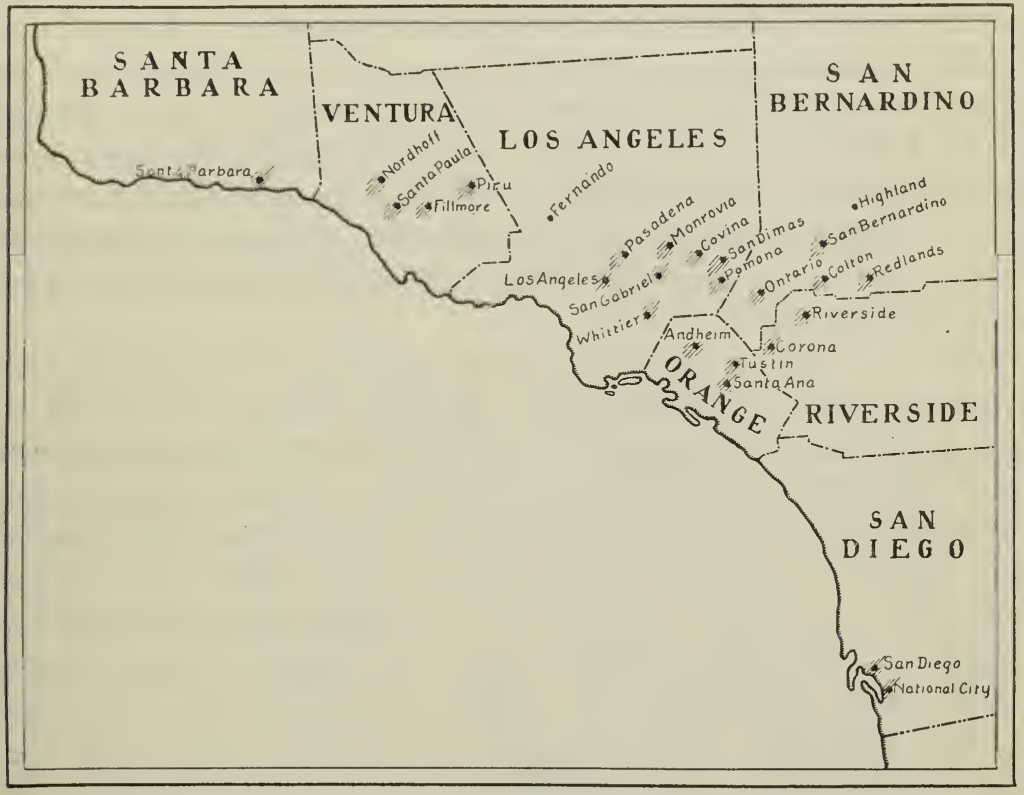

FIG. 2.-Distribution of Black Scale in Southern California.

tions it becomes an important pest. But the black scale becomes most abundant nearer the coast since it is a scale that is more adapted to the cooler and moister climate of such sections.

\section{ECONOMIC IMPORTANCE.}

The black scale is probably entitled to first rank as a citrus fruit pest in southern California. It has this place in Los Angeles, Orange, and Santa Barbara counties. This is based upon a report* of the respective horticultural commissioners of those counties. In two other counties, San Diego and Ventura, it has second place as a pest. First place in San Diego County is preëmpted by the purple, but because of the wider distribution of the black, it might be considered as the more important of the two. In Ventura County while the citrus mealy bug is put first, the commissioner states that practically all the control work is directed against the black. This is the real test of the economic importance of an insect, so that the black scale should be given first place in that county. In Riverside and San Bernardino counties the black ranks third as a pest. In these counties the yellow is given second place, but 
if we consider the red (Chysomphalus aurantii Mask) and the yellow (Chrysomphalus aurantii var. citrinus Coq.) as one species then the black will occupy second place in these two counties. It will be noted also that the Riverside commissioner stated that in 1910 seventy-five per cent of the control work was directed against the black. This, of course, is a higher percentage than is usual in that locality for the black scale. It should be mentioned also that where the purple or red is associated with the black, the control work is usually aimed at the other species, because they are more difficult to kill, that is, providing the time is chosen when the black is in the right stage. But if the black were allowed to go on untreated it would probably do as much as or more injury than the others.

Nature of Injury. The chief injury occasioned by the black scale is not due so much to the loss of sap through feeding, nor to the toxic effect on the tissues, as seems to be the case with the armored scales. That more or less injury of the above nature is done is not questioned, for it must be this largely that causes an actual killing of twigs where

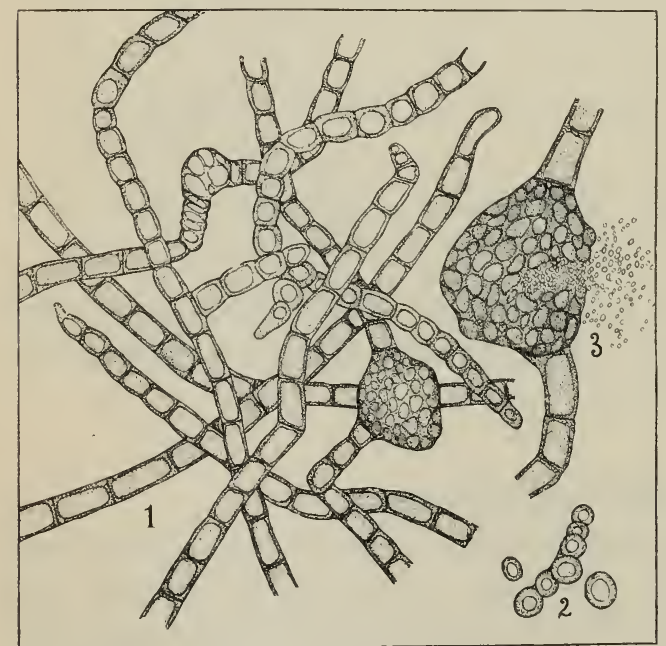

Fig. 3. - The sooty mold fungus. Much enlarged. 1. Mycelium. 2. Conidia. 3. Pycnidia with immature spores. From Florida Bulletin No. 53. the scales are incrusted upon them. But so far as citrus fruits are concerned, the important injury is due to the sooty mold fungus Meliola camellice (Catt) Sacc., which grows in the excretion, or so called honeydew. Large quantities of this honeydew are excreted, which falls upon the upper surfaces of the leaves and fruit, and serves as a medium for the growth of the fungus. This complete coating, as is often found on the leaf, interferes with the natural functions of the leaf by shutting off light. Light is necessary for the formation of starch and sugar, and consequently the sugar content of the fruit may be greatly reduced. The interference with the normal functions of the leaves also tends to diminish the general vigor of the tree.

But the great injury due to this scale is simply the presence of the sooty mold fungus on the fruit. For oranges or lemons to appear attractive and sell, they must be bright and clean. The proper way to get such fruit is to keep the tree free from the causative agent, in this 
case the black scale. But where the treatment is not properly done, or not done at all, the next best way to secure clean fruit is by washing. This operation in itself adds to the cost of handling, but the most important injury here is in rendering the fruit more likely to decay. With the fruit coming in contact with the sides of the tank, brushes, elevators, and drying racks, it is impossible to escape some abrasions, and into these abrasions the spores of the following fungi, with which the wash water may be infected, may find their way: Blue Mold, Penicillium italicum Wehmer; green mold, Penicillium digatum Sacc.; brown rot, Phythiacystis citrophthora Smith; cottony rot, Sclerotinium; Botrytis cinera Pers. and Aspergillus niger Van Tiegh.

\section{FOOD PLANTS.}

While the total list of food plants of the black scale is a long one, the number that is seriously infested is not large. In California it ranks first as a pest on citrus trees. On the olive, pepper and oleander, it also occurs in abundance, and often does much injury, but it is only rarely that control work is undertaken on these trees. Of the deciduous trees the apricot and prune are the worst attacked. On these trees Lecanium corni is often associated with the black, and is the more important pest of the two in the deciduous fruit sections. But the black scale often does reach the status of a pest on these trees and spraying is done to control it. It is not uncommon to see apricot trees completely covered with sooty mold fungus as a result of black scale infestation.

The plants named practically conclude the list on which the black scale is really an economic pest in this State. Many others are attacked, but are of interest chiefly in that they serve to reinfest those commercial trees that may be growing about them. It is not uncommon to find a citrus grove with the borders and avenues lined with peppers or olives. These serve as an excellent breeding ground, for they remain untreated. On the other hand, these trees are believed to be a distinct benefit because they insure the perpetuation of Scutellista, in the interim that the scale in the grove itself is recovering from the effects of fumigation. But if the grove is regularly fumigated, and the Scutellista thus ignored, such a claim is illogical. If the Scutellista, by being maintained on the peppers, tend to prolong the time for the next fumigation then they are a distinct benefit. Anyway, such shade trees as the pepper seem to be necessary for the comfort and æesthetic value they afford, and since it is impossible to prevent reinfestation with such an insect as the black scale anyway, to cut down such trees, as is sometimes advocated, hardly seems justifiable. 
The list of food plants from which the black seale has been taken is as follows: Orange, lemon, guava, irish juniper, lombardy poplar, apricot, prune, plum, almond, sycamore, oleander, pepper, Rhus, Heteromeles, Baccharis, Ficus, Habrothamnus, Myosporum, Melaleuca, laurel, holly,

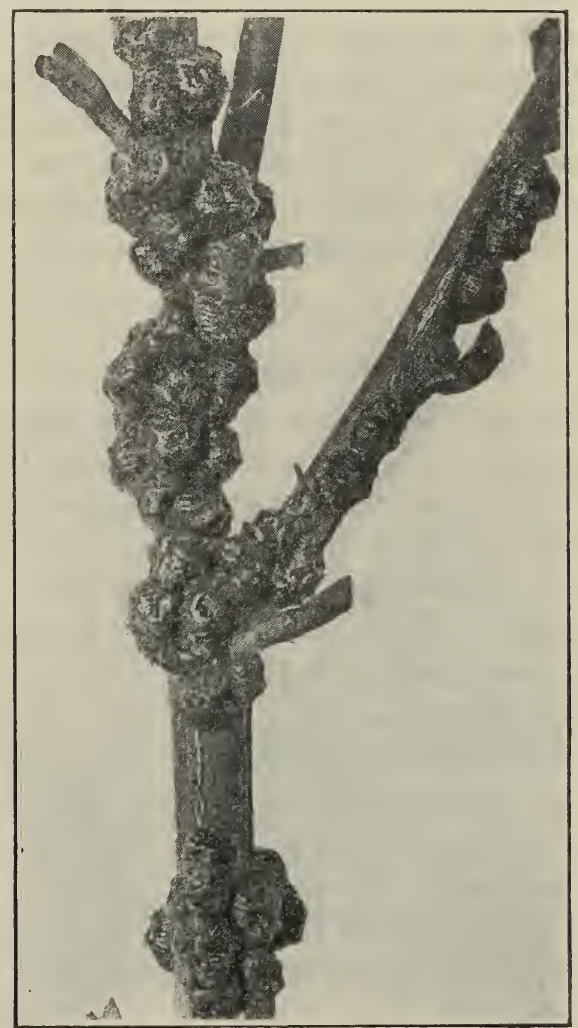

FIG. 4.-Black Scale (Saissetia oleae Bern.) on orange twig.

beech, ash, Rhamnus, Acer, Grevillea, Ligustrum, night shade, Antidesma, Duranta, Grewia, Thespesia, Cajanus, apple, pear, olive, pomegranate, Oregon Ash, honey locust, Magnolia, Eucalyptus, coffee, rose, Vitis, Camellia, Terminalia. 


\section{DESCRIPTIONS-LIFE HISTORY-HABITS.}

THE EGG.

Description. The eggs are oval in shape, measuring $.3 \mathrm{~mm}$. long and $.2 \mathrm{~mm}$. wide. When first deposited they are usually pearly white, but soon change to a cream color or with a pinkish cast. As the development continues they pass through different shades of pink until a few days before hatching they assume a reddish orange hue. The eye spots now appear and the embryo may be made out within.

Incubation Period. Several hundred freshly deposited eggs were placed in a pill box in the laboratory on June 9th. On June 24th a few hatched, about four fifths of the number hatched on the 28th, while the last hatched on the 29th. The minimum incubation period under these conditions was 16 days and the maximum 20 days. Other lots of eggs laid on June 16th hatched in from 19 to 21 days. During the winter season hatching may be prolonged for a month or six weeks.

Number of Eggs. Counts made of the number of eggs from 10 different seales of various sizes were as follows: 319, 220, 2073, 839, 2058, $2536,1340,1542,2894,2823$. The number will thus vary from about 200 to 2900 , the average in averaged sized scales will run close to 2000 eggs.

Percentage of Eggs that Hatch. In nearly all cases practically all of the eggs hatch. It is only very rarely that eggs will be found beneath the scale and not hatched. But it is rather common to find a large number of young dead beneath the parent. This is probably due to their inability to emerge on account of the arch at the posterior tip being in close contact with the twig or through the clogging of the opening by old egg. skins or young that have died from some other cause. It is possible also that extreme heat may kill the young before they emerge. Heat is an important factor in their mortality after they emerge.

Season when Eggs are Most Abundant. The eggs of the black scale may be found in certain localities at any season of the year. But by far the largest number of eggs occur in the spring during May, June, and a portion of July. At this season the great majority of the scales will be found with eggs in any part of the citrus area, but at other times there may be no eggs in certain groves, while in others eggs will be found. In this connection the time of fumigation may have an important influence on the stage of the insect, since all the young and partly grown may be killed, while the eggs under the adults will escape the effects of the gas. But there is, aside from this, a natural off hatch which occurs whether the tree has been fumigated or not. During the season of 1910 the largest number of eggs were present in the latter part of May. 
Relation of Weight of Eggs to Weight of Body. The following table gives the weight of the scale with and without eggs, the difference being the weight of the eggs alone. It will be seen that the eggs comprise a trifle less than one half of the body weight.

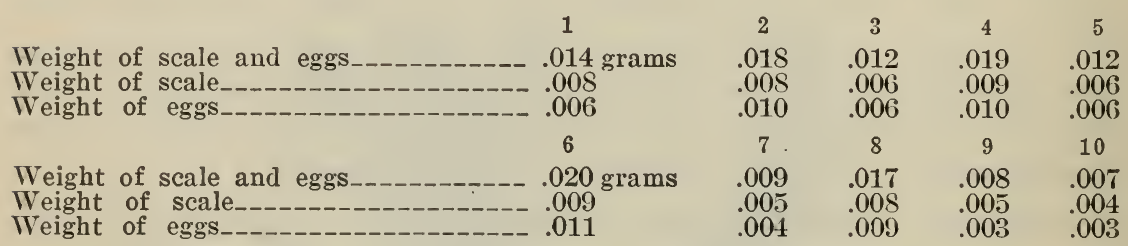

The 10 scales indicated in the above table were picked from the twigs with their full quota of eggs at that time. This was when the eggs were present in their maximum numbers. All of the eggs, of course, are not present at any one time, since the period of oviposition is greater than the hatching period. Consequently, more eggs would be deposited later so that instead of the weight of eggs being slightly less than that of the body as indicated in the table the total number laid will exceed one half the body weight.

Hatching Records. The scales represented in the following table were slightly under medium size. They were infesting oleander leaves and each one was surrounded by a ring of tree tanglefoot so that the young were imprisoned as they emerged. Each day they were counted and removed. The records of the 13th, 20th and 27th each represent a two days' hatch. It will be noted that the hatch roughly follows the temperature changes. During the cooler weather the young seem to remain under the scale longer and emerge in larger numbers on the next warm days. 


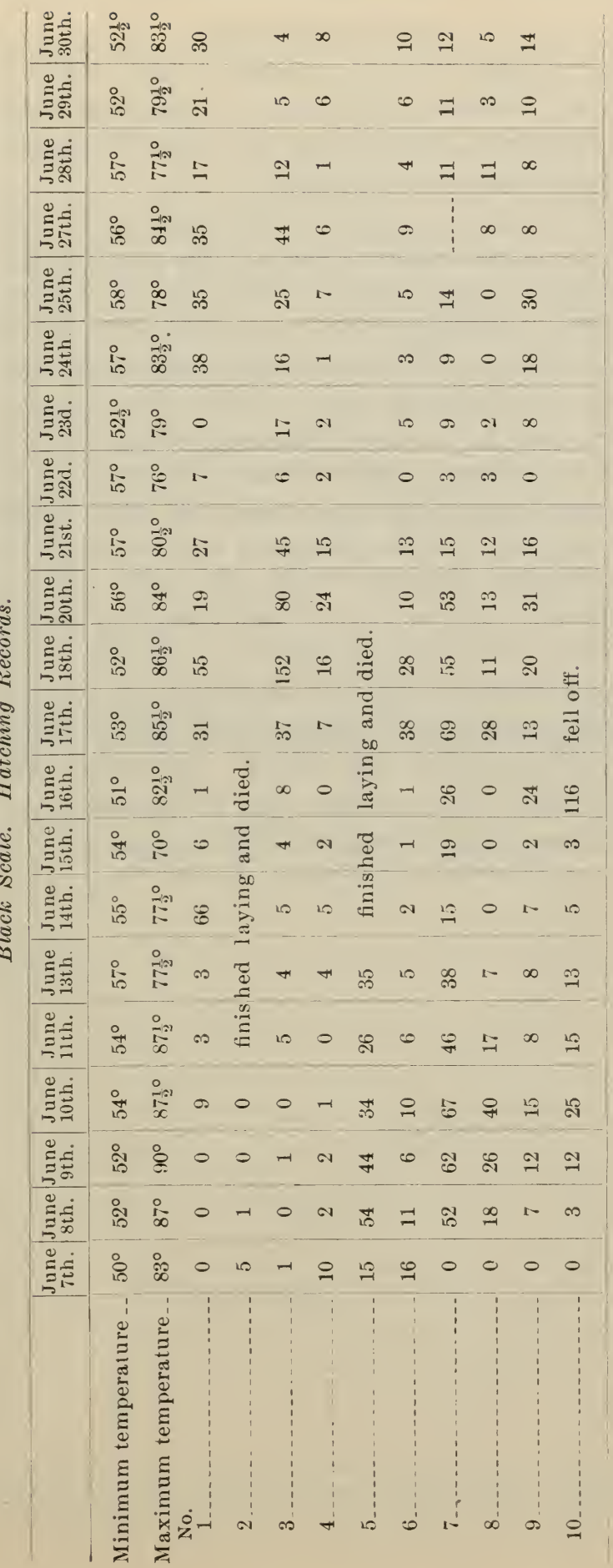


THE ACTIVE LARVA.

Description. Length $.34 \mathrm{~mm}$., width $.2 \mathrm{~mm}$. The color is light brown; eyes black, antennæ 6 segmented. From each of the oval plates there arises a long spine, slightly more than half the length of the body. The body is very flat and oval in shape.

Emergence. In all cases observed the young larvæ make their way from beneath the parent under the arch at the posterior tip. This arch consists of a slightly raised portion of the scale, for a short distance on either side of the anal cleft, which is not attached to the twig. This is large enough to permit of the exit of the young scales and occasionally two have been seen emerging side by side. The emergence occurs at about the same rate as the hatch, although many young will be seen under a scale at one time. But since about 40 eggs are laid in a day, this number may hatch at the same time, and these, together with the early or late hatching of others deposited near the same time, accounts for the large number that occur under the scale. They may remain under the scale for a day or two, so that when they emerge they have their full strength and begin immediately to actively crawl about.

Locomotion of the Young Larva. The distance traveled by the active larva on smooth paper was an average of 71 inches during a two-hour period when the temperature was $73.5^{\circ} \mathrm{F}$. The higher the temperature the faster they would travel, so that with a temperature of $90^{\circ} \mathrm{F}$. they traveled in the same time a distance of 151 inches. 


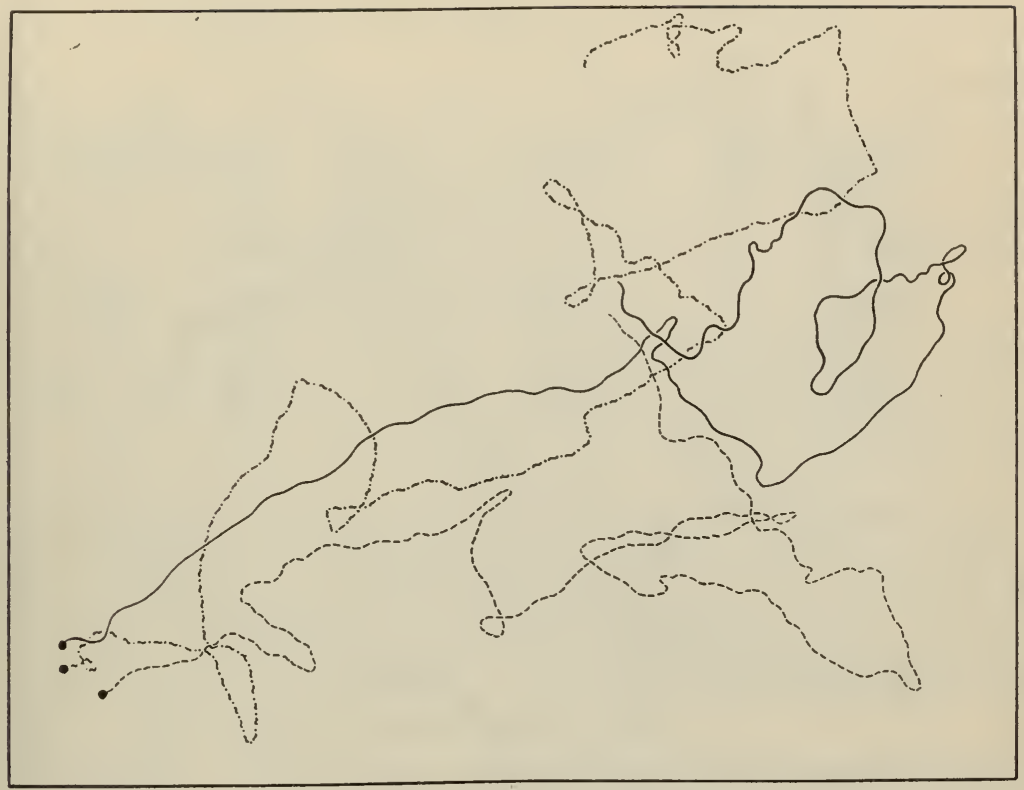

FIG. 5.-Tracings of young black scales for a 2-hour period. Reduced 7 times. Temperature 73.5 degrees. Average distance 71 inches.

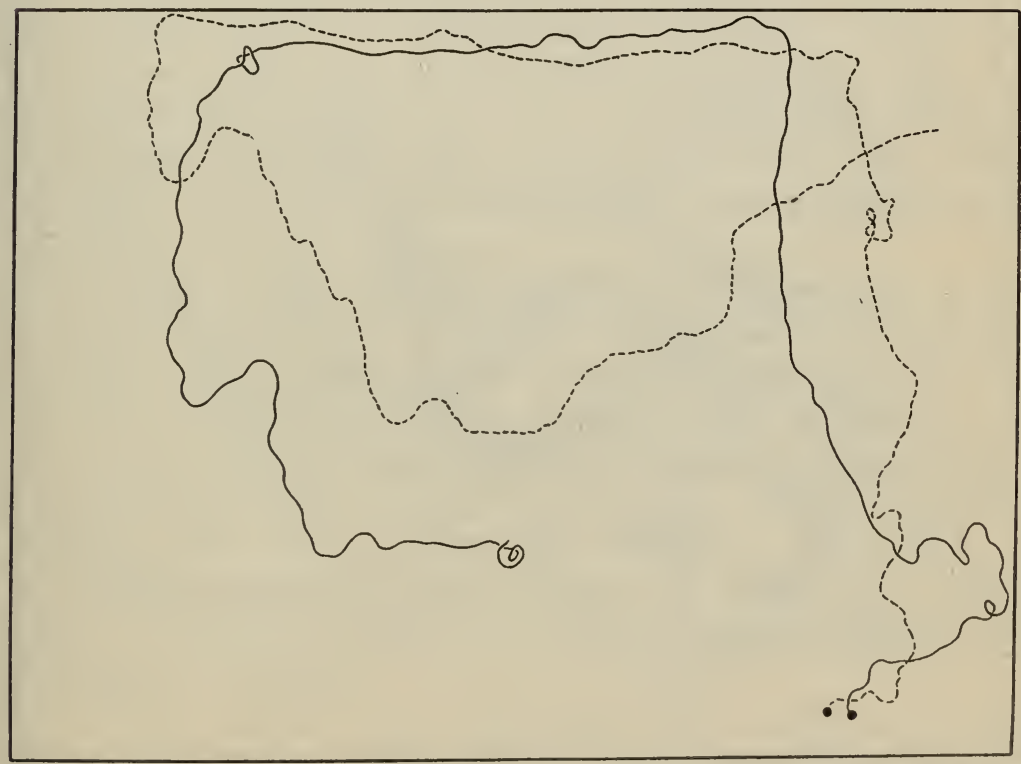

FIG. 6.-Tracings of young black scales for a 2-hour period. Reduced 7 times. Temperature 80 degrees. Average distance 76 inches. 


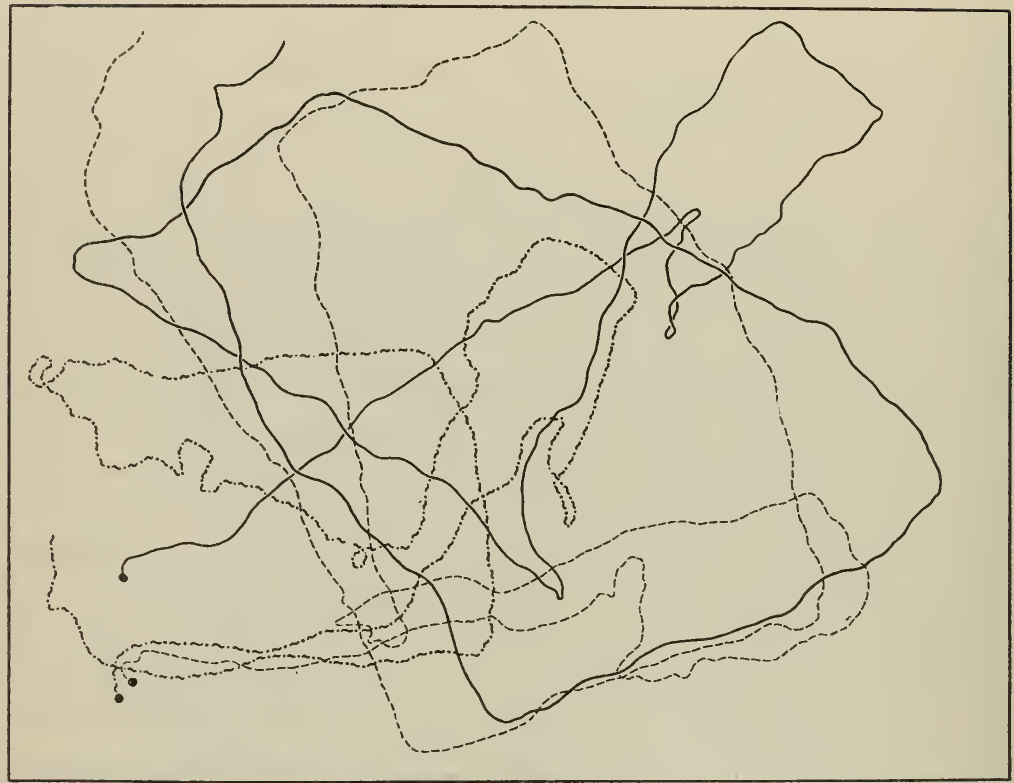

FrG. 7.-Tracings of young black scales for a 2-hour period. Reduced 7 times. Temperature 83 degrees. Average distance 123 inches.

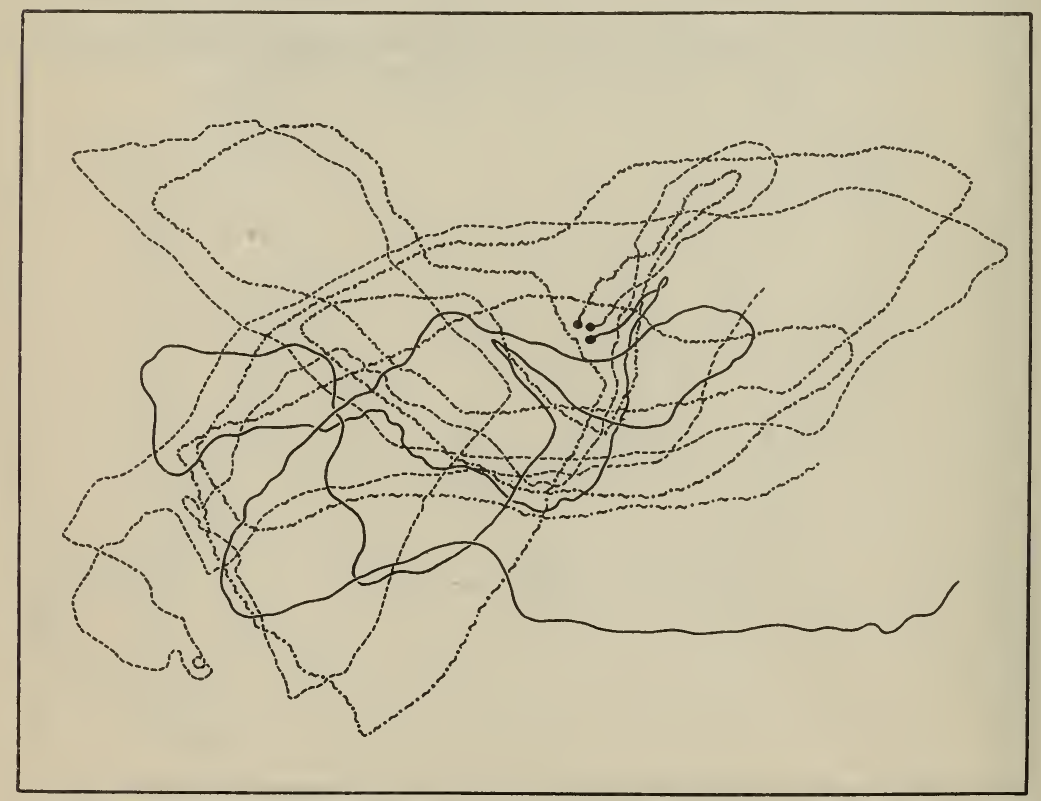

FiG. 8.-Tracings of young black scales for a 2-hour period. Reduced 7 times. Temperature 90 degrees. Average distance 151 inches. 
Table Showing Rate of Travel Over Smooth Surface.

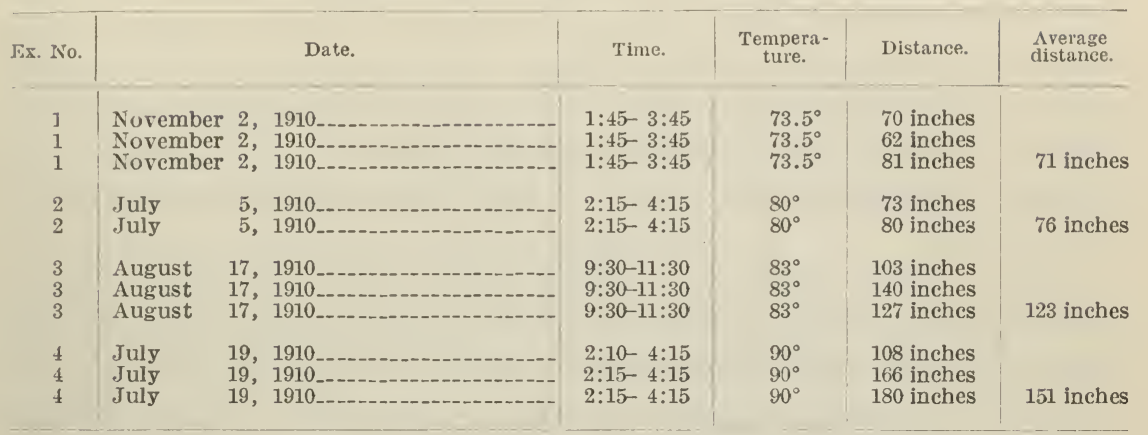

EXPERIMENTS ON RATE OF TRAVEL OVER SAND AND ORCHARD SOIL.

May 31,1910 . Temperature $84^{\circ}$ at point of experiment. $3: 30 \mathrm{p} . \mathrm{m}$. Several dozen young (taken from under adult) were placed upon leveled sand in a dish. At 3:55 one reached the edge of the dish, at 4:02 two more, and 5 more at $4: 30$. At 5 p. m. dozens had reached the edge of the plate. The distance traveled was 4 inches.

June 1, 1910. $10: 20$ a. m. Temperature $78^{\circ}$ at point of experiment. Several active young were liberated in the center of a plate of average lumpy orchard soil. In one hour 10 reached the edge; at noon about 50 more, and by 1 p. m. nearly all the young scale had reached the edge of the plate. Distance traveled, 4 inches.

June 1, 1910. $9: 15$ a. m. Temperature $74^{\circ}$ to $84^{\circ}$. Several hundred young were placed on a board covered with fine dust. By 1 p. m. nearly all had died, possibly from the suffocating effect of the fine particles of dust. The most active had traveled but 28 inches. Insects used as a check showed no ill effects under the same conditions excepting that they were on clean paper.

June 1, 1910. $10: 10$ a. m. Temperature $80^{\circ}$ at surface of sand. Several hundred young were liberated in the center of a dish containing sand with the surface smoothed over. This dish was then placed under a cover which allowed the light to strike strongly on one side. By $10: 50 \mathrm{a} . \mathrm{m}$. the majority of the insects had reached the lighted side of the box, having traveled 5 inches in 40 minutes. At 11:30 the dish was revolved $180^{\circ}$ and the insects again thrown in the shadow. By 1 p. m. they had crossed the plate, a distance of 10 inches in $1 \frac{1}{2}$ hours. At $1: 30 \mathrm{p} . \mathrm{m}$. the dish was again revolved and the insects again crossed the 10 inches in $1 \frac{3}{4}$ hours.

June 3, 1910. $10: 15$ a. m. Temperature $85^{\circ}$. A plot of average orchard soil was enclosed within strips of paper each 2 feet long. In the center of this area of soil 400 or 500 active young were liberated. By $12: 30$ p. m. about 20 insects reached the edge; by 1 p. m. nearly 50 and at 5 p. m. about 100 . Distance traveled, 1 foot. 
June 3, 1910. 10:15 a. m. Temperature $85^{\circ}$. A plot of orchard soil one foot square was enclosed in paper and in the center of this several hundred young were placed. At the beginning of the experiment the morning was foggy. At 11:05 three insects reached the paper, a distance of six inches. By this time the sun was appearing and the temperature rose to $96^{\circ}$. Later $102^{\circ}$ was reached and all the insects died.

June 9, 1910. $10: 00$ a. m. Temperature $73^{\circ}$. A plot of ordinary orchard soil two feet square was enclosed with strips of paper. Several thousand scales just removed from beneath adults were liberated. At 11: 30 four reached the paper and at noon 20 more. Temperature at this time was $76^{\circ}$.

The same experiment was repeated on the following day with a temperature of $72^{\circ}$ to $86^{\circ}$. By 2 p. m. about 75 insects reached the paper. The same was repeated on the following day, when 8 scales reached the paper in 1 hour and 5 minutes, and 24 in 3 hours and 50 minutes.

July 18,1910 . Temperature $80^{\circ}$, humid. Fifty young were placed in the center of a plot of sand 6 inches in diameter. In 30 minutes 5 reached the black paper on which the sand was placed, and in three quarters of an hour one half of the insects had reached the paper. Distance, 3 inches.

From the above experiments it will be seen that the young black scale is capable of traveling some distance over ordinary orchard soil, but the percentage traveling any distance is very small. Much greater progress is made on a compacted soil than over a fine mulch. It may be possible for a young black scale to make its way from one tree to another, but the number that will travel that distance over a mulch is exceedingly small. In the case of soil compacted after a heavy rain or in an irrigation furrow, it is possible that they would reach even the second or third tree away. During the time of irrigation they may also be carried by the flow of the water itself.

Other Factors in the Spread of the Young Scale. A foot bellows was arranged so as to throw a current of air against a white screen. The maximum velocity of air from this bellows was stronger than the wind ever blows in the citrus belt. A branch containing active young scales was placed in this current, but none were displaced until the branch was lrought to within six inches of the mouth of the bellows. Even then many withstood the extreme velocity, thus showing that the wind, as it ordinarily blows, can not be counted a very important factor in dislodging the young black scale. Once the scales were dislodged, they were carried a short distance as they fell.

Several rags, sticks, pieces of boards, and a pair of gloves were placed 
in a tree badly infested with the young black scale. Later, when these were examined, many young were crawling about over them. It is altogether likely, therefore, that ladders, gloves, clippers, picking boxes, and other things used in the harvesting of the fruit are possible means of infesting a clean grove if these things are immediately or soon used in the grove. While, then, these things are possible sources of spread, they are not so important as natural agencies.

About 100 Coccinellids were confined for a day in a jar containing olive branches badly infested with black scale from which young were issuing. Upon examination it was found that young scales were being carried about by the beetles. About one beetle in every 10 or 15 carried from one to four scales. The slower moving beetles were most likely to carry the scales. These beetles have also been seen under the natural conditions of the field to have young scale crawling upon them.

What has thus been actually observed in the case of Coccinellids is likely to occur also with other insects that frequent scale-infested areas. Among these, ants may be mentioned, but these are not likely to transport them long distances, for their nests are usually close at hand. The larvæ of Chrysopa and Hemerobius which may feed among the scales may also be guilty of spreading the scales, and possibly also the adults of these species. Winged Aphids are also found commonly on orange trees in the early spring, principally, but these are more apt to be confined to the tender growth which has not yet become infested with scales. But of all the active insects found on the orange tree the Coccinellida are probably the worst offenders in spreading young scale.

Length of Life Without Food. Two or three hundred eggs were taken from under each of several scales and as the young hatched they were placed in pill boxes without food. One lot lived about 52 hours; another 60 ; a third lot (the majority about 60 hours), while a few lived for 65 hours; lot 4 lived 56 hours; lot 5 were removed from under the adults alive; these lived 84 hours; lot 6 were similarly taken from beneath the parent and they lived 84 hours. Lots $7,8,9,10$ were all taken alive from under the adults and lived 66 hours without food. It thus appears that between 3 and 4 days is the maximum time that young black scale will live without food.

Experiments on the Effects of Temperature on the Young. May 31, 1910,2 p. m. Temperature $115^{\circ}$ F. in sun at surface of ground. Sevcral hundred active young (taken from under adult) were liberated on ordinary orchard soil. At 2:15 when again examined all were dead, not having moved more than 2 inches.

June $30,1910,11$ a. m. Temperature $80^{\circ}$ in sun 4 feet above soil. 'Jemperature $120^{\circ}$ with bulb in soil at point of experiment. Several 
hundred young liberated on ordinary brown colored soil died within 10 minutes.

June 30, 1910, 11:05 a. m. Temperature in sun 6 feet above ground $80^{\circ}$, slight wind. Temperature at surface of paper $104^{\circ}$ to $110^{\circ}$, sheltered from breeze. Active young removed from parent were liberated on white paper under above conditions and remained active for 2 hours, after which observations were discontinued.

June $30,1910,10: 25$ a. m. Temperature $94^{\circ}$ to $100^{\circ}$ at surface of cardboard. Young scales were placed on this where they crawled about for 2 hours unharmed by the heat.

July 6, 1910. Liberated a number of young from under adult on white paper in the sun. Temperature $106^{\circ}$ to $110^{\circ}$. Temperature 4 feet above ground, $98^{\circ}$. At $106^{\circ}$ they were very lively, but as the temperature increased they moved more slowly and at $110^{\circ}$ almost all movement ceased, although a 2 hours' exposure did not kill them.

July 6, 1910, 11 a. m. Temperature $118^{\circ}$ at surface of board mentioned below. A large number of active young, taken from under female, were placed upon a brown colored board. Within 5 minutes all the scales were dead.

July 7, 1910, 11 a. m. Temperature $130^{\circ}$ at surface of soil. Temperature $100^{\circ}$ four feet above ground in sun. Several young from under female were placed on ordinary orchard soil under above conditions. Death resulted within 5 minutes. Insects used as a check in the shade were perfectly normal.

July 8, 1910, $10: 30$ a. m. Temperature $119^{\circ}$ to $122^{\circ}$ at surface of soil. A large number of young were placed upon eommon orchard soil under above conditions. After 15 minutes they were again examined and found dead, a check lot in the shade remaining normal.

Effects of Light. Several experiments, which will not be detailed here, were undertaken to determine the behavior of the young black scales toward light. In all cases they responded to the influence of light, showing them to be positively phototropic.

In the case of older scales, that is, when they migrate from leaves to twigs, since they almost invariably become fixed on the under side, it would appear that they later in life become negatively phototropic.

About 100 active young scales, secured from beneath a female, were placed upon the middle of an upright stake. Some immediately crawled downward, but a large majority crawled upward. Upon reaching the top these did not remain there, but crawled down again, many going directly to the bottom. A little later they became distributed all over the stake. Here the effects of the light were not removed so that it can not be stated whether they have a tendency to go up or down. But 
judging from observations in the field there appears to be a tendency to migrate upward.

Where the Young Settle. The large majority of the young in most (ases select the leaves as a place to settle. They may choose either the upper or lower surface. If the leaves are exposed to the sun they are more apt to settle on the lower surface. If, too, the upper surface is covered with sooty mold fungus, as is often the case, they are more likely to select the cleaner side of the leaf.

In case the twigs are still tender a considerable number of young may settle there. They have also been observed to settle on stems that contained more or less of the corky wood. But the majority upon first settling select the leaves or tender stems. To be sure, the old scales are found on very large limbs, but it is only rarely that the active young settle there. The old are found there usually because of their migration after they have attained some size on the more tender parts of the tree.

The reason for thus selecting the more tender parts of the tree is because the tissues are more easily penetrated by the small scales, and because the liquid parts of the plant are nearer the surface and more easily obtained. There is a tendency of many scales to settle along the midrib and along the larger veins. They fix themselves parallel to the midrib with the central line of the body at the bottom of the ridge, one half extending up on the midrib and the other half on the leaf surface. This may be partly for protection since there is a distinct groove here, but more probably because the sap is more readily obtained at this point.

On June 12, 1909, 160 active young were liberated on twigs and leaves, 80 on the twigs and 80 on the leaves. Upon examination on June 24th, 35 were found established, and these all on the leaves.

On the same date 150 scales were distributed in another place and on the 24th of June, 57 were found on the leaves, largely along the midrib. On July 30th only a very few remained alive, and an occasional one was seen on the branch.

On June 10, 1909, 12 young black scales were distributed on each of the leaves of a terminal twig, excepting the lower two. Fourteen days later the scales which had settled were distributed as follows: 5 on four leaves, 7 on two, 13 on one, and 4 and 2 respectively on each of the two lower leaves on which none were actually liberated. The last examination, which was made on September 21st, found them still on the leaves.

The end of a lemon branch was isolated with tanglefoot and an infested olive branch from which young were emerging was entangled in the twig. Three weeks later many had settled on the leaves and tender branches, most on the upper side, fewer on the lower side and least on the tender twigs. Later the majority of those dead were found 
on the upper surface. This experiment was carried on in several different places in the Laboratory plot and the results were the same in each case.

The following table gives the record of those settling in our breeding experiments in the insectary. Out of 236 liberated 53 or 22.88 per cent settled :

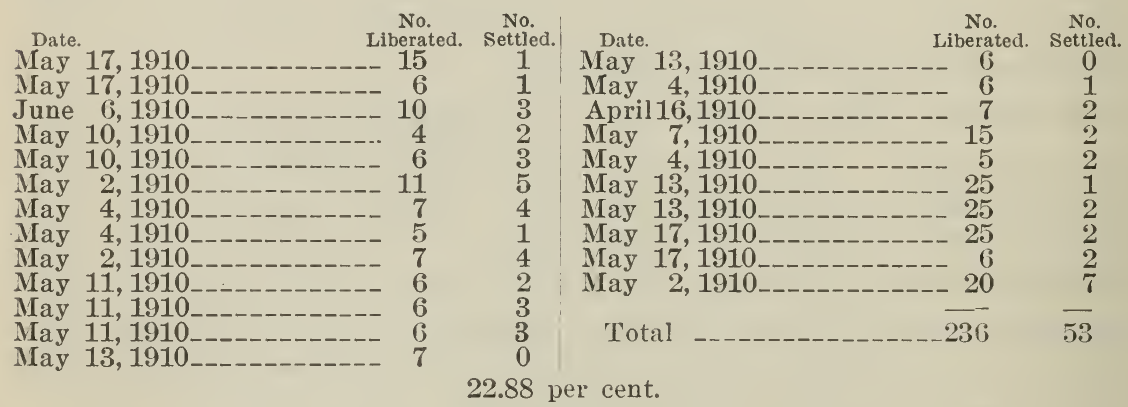

Proportion of Young Becoming Fixed. We have shown that in the case of the red scale about 41 per cent fails to become settled. The purple is a little more successful in this respect, but the black seems to be the least successful of the three. In thousands of scales liberated we have often got a mortality as high as 95 per cent before they became fixed. In other cases a larger per cent will establish themselves. There appears, therefore, to be a very wide variation in the per cent that may settle, but on the whole it is very small. The same facts have been recorded both from the insectary and the field. Immense numbers of young scales have been found settled in the field where the number of adults was not especially large. Again, where the adults are extremely abundant the young have been found to be very scarce. This statement is made too with due regard for the presence or absence of the egg parasite, Scutellista.

\section{THE FIXED YOUNG.}

Development Before First Molt. Soon after settling the young scales become flatter and somewhat larger in area. The scale preliminary to the first molt is just about twice the size of the young after hatching. The length at this stage is $.7 \mathrm{~mm}$. and the width $.35 \mathrm{~mm}$., as compared with $.35 \mathrm{~mm}$. in length and $.2 \mathrm{~mm}$. in width before settling. The anal plates instead of being at the extreme tip of the scale, as in the active iarva, are now drawn considerably forward, or rather the posterior margin of the body has extended backward, and the two lobes inward, so that the plates are enclosed in a triangular space some distance from the tip. The long spines are still attached to the anal plates but, on account of the plates being so far forward, they do not extend as far beyond the tip of the body. The different relative position of the anal 
plates and the character of the anal cleft, it now being practically closed behind the plates, is the most conspicuous change, aside from the size, undergone during the first stage.

The First Molt. The first molt occurs from a month to six weeks after birth during the summer months, and this may be prolonged to two months or more during the winter season. There is considerable variation in the time of molting, even though the scales be of the same age, and under the same conditions. We have found this same fact true for the cottony cushion scale, there being as much as two months difference in the time of development of individuals, hatched on the same day and living under identical conditions. This may be partly due to possible differences in food supply, as well as to individual differences in the scales themselves.

Development Between the First and Second Molts. The change undergone after the first molt is not very striking aside from the beginning of the formation of the letter $H$. At this time the ridge that forms the bar of the letter extends from one end of the scale to the other. Later the two ends become obliterated and after the second molt the true $\mathrm{H}$ appears.

The Second Molt of the Female. This occurs on an average from about two and a half to three months from birth, during the spring and summer months. In winter this period may be considerably prolonged. While there is more or less variation in the time of the first molt, under the same conditions, there is still more variation with the second molt. This molt brings the female scale to the adult stage.

Process of Molting. The process of molting in the black scale, like other unarmored scales studied as Coccus hesperidum and Saissetia hemispharica, consists of a splitting of the old skin at the anterior end and then a pushing of this backward until it is free from the insect.

The cast skin, which is a very minute frail object rolled up more or less, may sometimes be caught still adhering to the posterior tip of the body. But in breeding cages, sealed on the leaf with paraffin, we had no trouble in detecting these after they were completely removed from the body. Often times they look not unlike a film of cotton, and the velvet which was first used in our cages to prevent the insects from escaping, gave us much trouble in distinguishing the molted skins. The antennæ beak, legs and all other integumentary structures go with the molted skin.

Effect of Temperature. The effect of high temperatures has already been noted in the case of the active larvæ. But even after that stage they do not escape, and so, after the scales become fixed and have grown to some size, hot weather periods are likely to kill them off in very large numbers. A survey of the black-scale-infested territory a week or two 
after one of these hot spells will show that in some cases almost the complete generation is killed. Scales may, of course, be found dead in considerable numbers without a well-defined hot weather period. But the killing is much more pronounced and uniform after such a period and it seems logical to attribute such a condition to it.

Honeydew and Fungus Growth. The excretion from the black scale, when it falls upon the surface of the tree, offers a very suitable medium for the growth of the sooty mold, Meliola camellice (Catt) Sacc. This fungus is associated with all the other unarmored scales and also with the insects of the families Aphididce and Aleyrodida, as well as others of less importance in the quantity of honeydew excreted. This fungus is a saprophyte, and derives its sustenance from the honeydew. It is not, therefore, directly injurious to the tree as a parasitic fungus would be. Indirectly, however, it does do damage to the tree and especially to the fruit, as previously explained. The characteristic black covering formed over the plant is due to the vegetative threads of the fungus. It is spread about from tree to tree by the agency of the wind in transporting the spores.

Relation of Ants to the Scale. It very commonly occurs that trees infested with the black, as well as other unarmored scales and particularly the soft brown, will have ants running about over them. The ants are there for the purpose of getting the honey as it is excreted by the scales. The ants by a stroking with their antennæ induce the scales to give up small droplets which are immediately taken into their bodies. The ants usually do no harm to the tree directly, unless they happen to be nesting in large colonies about the roots. Occasionally they do attack the tender growth, eating the tissues of the leaves and the tender twigs. But indirectly the continual movement of many hundreds of ants over the scales may tend to prevent oviposition by the parasites of the scales. This is especially likely to be true in the case of the Argentine species which infests the tree in such immense numbers. On the other hand, cases have occurred where the ants were really a benefit. The chief injury, after all, in the case of the black scale is in the honeydew and consequent sooty mold rendering unsightly and unmarketable the fruit. Ants have been seen numerous enough to take up all the honeydew just as fast as it was excreted and completely prevent any sooty mold from forming on the plant surface.

Movement After Settling. As already explained, the young larvæ settle largely upon the leaves. This is true also in the case of deciduous trees. It is also true of such other unarmored scales as have a similar life history, as the European Fruit Lecanium (Lecanium corni). In the case of such scales on deciduous trees, they must migrate from the leaves at some time because the dropping of the leaves in the winter 
would prevent them from maturing. And so they do transfer themselves to the twigs as the leaves complete their growth in the fall and hecome yellow and dry. Many also fall to the ground with the leaves, and a large number of these must perish.

The same vital need for transferring themselves from leaf to twig does not prevail in the case of the black scale on citrus trees. But it is a fact, nevertheless, that only a very few adult black seales are ever found on the leaves. There is, therefore, a transfer from leaf to twig, since the majority of the young settle on the former. This occurs when the scale is partly grown. The exact time varies greatly and is probably dependent upon the food supply. In the case of the young first settling

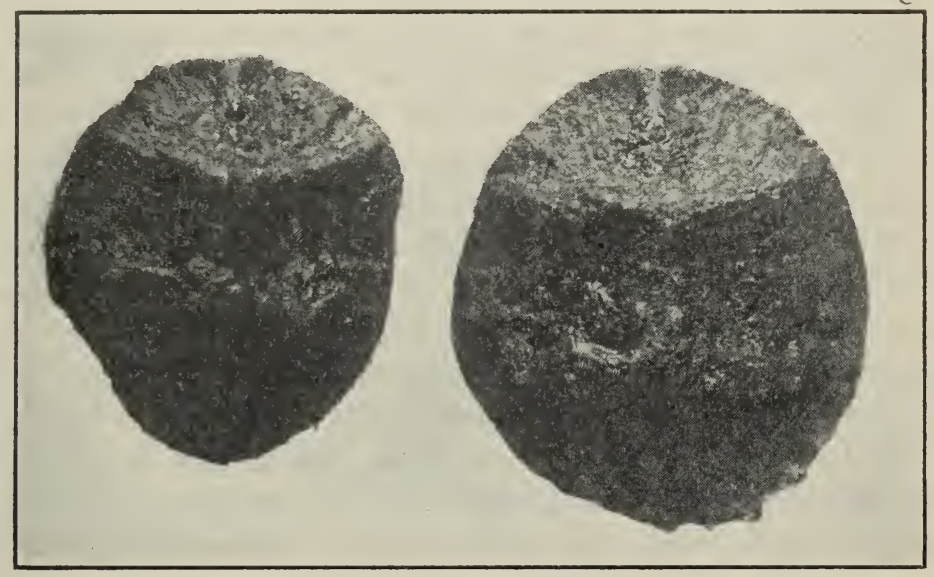

Fig. 9.-Mature Black Scales.

it has been stated that the leaves are chosen because of the tissues there being more easily penetrated and the liquid food nearer to the surface, and thus more likely to be available through the short beak of the young. On the other hand, as the scales become older and the beak larger and stronger, they are more likely to get a greater supply of food from the twigs, through whose tissues they are at this time able to penetrate. But it may be an instinctive provision, too, to choose the more permanent part of the tree for their final resting place. While a leaf on a citrus tree may remain for two or three years, on the other hand it is liable to drop off as in the case of a deciduous tree.

A drying of a leaf or some other abnormal condition will cause the scales to loosen their hold and move about while they are still very young, that is, before the first or second molt. But ordinarily the greatest migration occurs later and after the second molt. This period from settling, will thus be after three months and later. Scales have been observed moving about when they had attained a length of $2 \frac{1}{2} \mathrm{~mm}$. The smallest mature scales do not exceed this length, though they are, of 
course, greater in height. Usually in the migrating stage they are still elongate and not so broad as they become later. But many in the so-called rubber stage have that broadened effect, and will be seen moving about looking for a suitable place to become permanently fixed.

\section{THE ADULT FEMALE.}

After the second molt, which brings the female to the adult stage, there is a very great increase in size, and also in general form. The more or less elongate scale lying flat on the surface is now almost round, and has become greatly thickened. The letter $\mathrm{H}$ is very distinctly outlined on the dorsal surface. As it approaches the egg-laying stage many specimens become a dark mottled gray. When egg-laying is begun, the scale takes on a more leathery, smoother surface and also becomes much darker in color, this varying from a dark brown to a jet black.

The size of the adult varies from a height of 1 to $3 \mathrm{~mm}$.; length, $2 \frac{1}{2}$ to $5 \frac{1}{4} \mathrm{~mm}$.; width, 2 to $4 \frac{3}{4} \mathrm{~mm}$. This represents about the extremes in size, and individuals will be found at all sizes between these dimensions. Usually on the same tree the majority of the scales will be of about the same size. Nearly always on young, healthy trees the scales will be vigorous and of good size. In other cases, and frequently on olive trees, all the scales will be small. The condition of the tree, and the number of individuals, appear to be the most important factors in determining the size. Where the scales are simply crowded against one another, and deformed for lack of room for normal growth, they are usually of small size.

Oviposition. Usually from eight to ten months are necessary to bring the female to the egg-laying stage. The number deposited varies from 200 to about 3,000 , with an average of 1,500 or 2,000. The oviposition period lasts from six weeks to two months or longer.

On May 7, 1910, several solitary scales were selected on oleander leaves and each enclosed with rings of tanglefoot. Young were issuing from under them at the time, so that they must have begun egg-laying at least 20 days previously. On the 31st of July young were still issuing from under the adults. When these were overturned there were still enough eggs to hatch for a week longer. The known egg-laying period is thus 55 days, and the evidence points to at least 10 days longer. On the 10th of August the last eggs hatched from one of these seales, making a known length of 64 days, with possibly a week added on to this at the beginning. A good healthy black scale will, therefore, deposit an average of 30 or 40 eggs a day for a period of 60 days. If an egglaying female is removed from its natural resting place, it will continue to deposit eggs for several days. The following table gives the results 
of isolating egg-laying individuals in pill boxes to determine the extent of oviposition when removed from their food plant. The scales were taken from the twigs and all eggs removed on May $3 \mathrm{~d}$ :

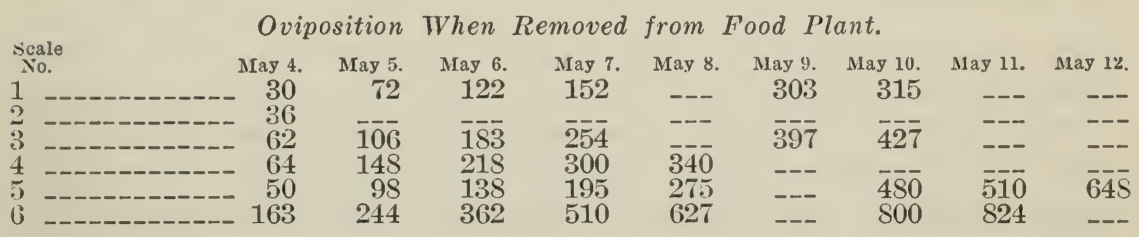

THE DEVELOPMENT OF THE MALE.

While the black scale is very widely distributed over the world, little has been known and practically nothing published about the male. It was first described by Dr. B. W. Griffith* of Los Angeles in 1893. It was thus said to be limited to a small area in the vicinity of Los Angeles. During the past year or two we have taken it at various places in the citrus belt from Santa Barbara to San Diego. It seemed to be especially abundant during the season of 1909 . In places where it occurred that year, it was not nearly so abundant on the previous year or the year following. As many as 97 puparia, from all of which males had emerged, have been seen on a single orange leaf. The males have been taken from the leaves of orange, oleander, pepper and olive. They emerged during the months of June, July, August, September, October, November, December, and possibly other months, though not actually observed.

The Second Stage Male. Up to the time of the first molt there is no difference between the sexes. After the first molt the male becomes decidedly more elongate, resembling more nearly a partly grown soft brown scale. Its length is $1.5 \mathrm{~mm}$. and width .64. It is of a light brown color with the eyes visible in the latter part of the stage as small dark areas on the front margin. The anal plates together form a triangle with rounded corners, and from the tip of each of these there arises 3 or 4 small spines, and one large one on the central dorsal surface.

The length of time spent in this stage is about four weeks. During this time it is feeding and grows to about 5 times the length of the justhatched larva. At the end of the stage a puparium is formed which completely covers the insect although it is transparent and not so readily discernible.

The Male Puparium. This puparium is a glassy-like covering that is formed from the secretion of numerous pores over the body surface. Its length is $1 \frac{1}{2} \mathrm{~mm}$. and width $.5 \mathrm{~mm}$. The surface is slightly roughened with a row of granular projections along the dorsal line. Two lines beginning at the anterior end converge upward for a short distance and then run more nearly parallel, with but a slight convergence toward the 
posterior end. Within this the surface is more convex, forming a ridge along the dorsal line. Not quite one quarter of the distance from the anterior end and at a point where the lines begin to run parallel, is a cross line or carina. Another lateral carina crosses this dorsal strip, or. coronet, at one quarter the distance from the posterior end. Immediately posterior to this cross line are two spiracular channels extending to either margin. The other two spiracular channels, extending from the coronet to either side, are just before the middle line. There is a triangular opening for the anal plates and a cleft from this to the posterior end. Along the margin is a series of circular pores from which secretions extend to the surface of the leaf, thus holding the puparium in place. When a puparium was removed 3 or 4 weeks after the male
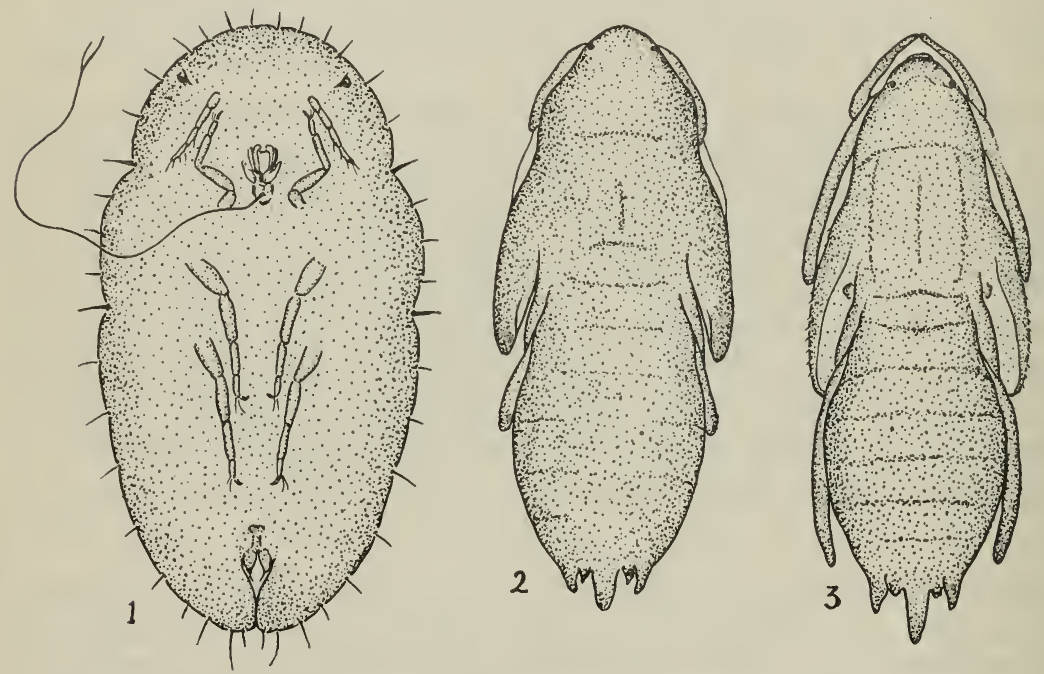

FIG. 10.-Development of the male of the Black Scale.

1. Second stage. 2. Propupa. 3. Pupa. $\times 40$.

had emerged, these connecting threads were still capable of being stretched considerably as was observed upon lifting the puparium.

These are found usually on the under side of the leaves of the orange, pepper, olive and oleander, chiefly, since these constitute the principal food plants of the scale. When the insect is still beneath it can be detected through this transparent covering. If it has not yet transformed to the propupa it occupies the entire space beneath extending well out to the margins, but in the case of the later stages the insect beneath is somewhat narrower. These puparia may remain on the leaves for months after the scale has emerged.

The second stage male is capable of moving up to the time the puparium is secreted, which is the preliminary step in the change to the propupa. But it is only rarely that any movement occurs in this 
stage, and hence the males are nearly always found on the leaves where the young first settle.

The Propupa. Length $1.4 \mathrm{~mm}$., greatest width $.4 \mathrm{~mm}$. Color light brown with red pigment scattered about, particularly at posterior end; head reddish; eyes dark red or brown. Sheath of style short and blunt; on either side of the style are two more slender and pointed appendages, the cerci extending beyond the style. At the tip are a few short hairs or spines. The sheaths of the antennæ and legs are scarcely visible on the dorsal surface excepting a broadening, where these lie on the ventral margin. On the ventral side these are plainly visible, and lie in close contact with the body. The length of the propupal period is from 5 to 8 days during the warmer weather.

The Pupa. Length $1.2 \mathrm{~mm}$., width $.4 \mathrm{~mm}$., general color same as that of propupa, excepting that there is a larger amount of pigment at the anterior end. The head is entirely red. A marked constriction forms the neck making the head appear as arrow-shaped. Eyes black. The wing pads are conspicuous and extend to third abdominal segment. The style has increased in length so that it is slightly longer than the cerci on either side. The antennæ, legs and wing pads, while naturally lying close to the body, are distinct and readily separated from it.

Eight to twelve days are spent in the true pupal stage, when it changes to the adult. In all the molts after the second stage the skin is split at the anterior end and pushed back beyond the puparium.

The Adult Male. The fully developed male remains from 1 to 3 days beneath the puparium before emerging. The adult stage can be determined without the removal of the puparium by the appearance of the long white caudal filaments which project out beyond the tip of the puparium. The life of the adult male is from one to four days. The following description of the male is copied from the notes of Prof. R. W. Doane, who worked with the writer during the summer of 1910 :

Length exclusive of style $1 \mathrm{~mm}$; style $.4 \mathrm{~mm}$; caudal filament $8 \mathrm{~mm}$; antennæ $5 \mathrm{~mm}$.; wing $1 \mathrm{~mm}$. long, $.5 \mathrm{~mm}$. wide; honey yellow; head darker yellow; anterior pair of upper

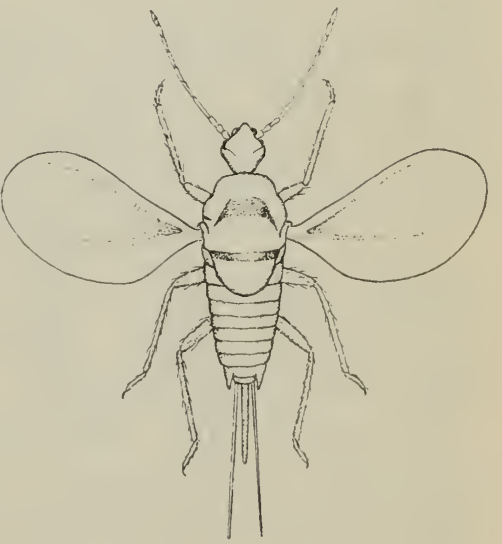

FIG. 11.-Male of Black Scale. $\times 25$. cyes dark red, posterior pair black, smaller; ventral pair black equal in size to the upper anterior pair. Antennæ whitish, 10 jointed, first joint short, thick cylindrical; second joint about equal to first, but 
oval; third joint about as long as second, but much more slender, slightly swollen toward the tip; remaining joints all slender, cylindrical, fourth as long as fifth and sixth together; others subequal in length, collar long, cylindrical; prothorax broad shield shaped; mesothorax more strongly chitinized and wholly brown except a yellow shield-shaped area above, between the bases of the wings; metathorax with a slight brownish tinge; legs brownish yellow; style yellow; caudal filaments white, slender, tapering, twice as long as style; wings hyaline with a yellowish tinge, with a microscopic close-set pubescence.

The above description is given in detail because the original description given by Dr. Griffith is incomplete. The only figures of the male that have appeared from original specimens are given by Marlatt in the United States Department of Agriculture year-book for 1900. "In the figure of the adult there given the black bands are not properly placed. Both are too far forward, the first is not broad enough, the second too broad, and the yellowish spot between the wings does not reach to the base of the wings." -Doane.

When the males emerge the females that hatched at the same time have completed their second molt, and the letter $H$ is evident. Summarizing the length of the life cycle of the male it will be during the summer months as follows: 1st stage, $1 \frac{1}{2}$ months; $2 \mathrm{~d}$ stage, 1 month; propupa, 8 days ; pupa, 10 days; adult, 3 days; total, 96 days; or about 3 months.

\section{SEASONAL HISTORY.}

Number of Generations. There is usually but one complete generation of the black scale in a season. The great majority of these come to maturity in the spring months, so that most of the eggs are deposited by midsummer. The time of maturing of the bulk of the black scales will vary somewhat from year to year, and in some years there will be a much more uniform hatch than others. Taking a specific season, as 1910 in the Los Angeles district, the height of egg-laying was during the third week in May. The greatest production of young was about the third week in June. Eggs will be deposited by a single scale during a period of two months. By the middle of July, therefore, most of the young had already appeared.

On June 3, 1910, sixteen different lots of young black scale were distributed in twig cages on different orange trees. These remained small throughout the summer, fall and winter, beginning to grow rapidly in February and March, so that, when examined on April 26, 1911, some had not yet begun egg laying, others had just started, while others had been depositing eggs for a week or two. By the middle of May or first of June, young were emerging from most of these scales. Practically one full year was thus necessary to bring these scales from the period 
of active young to the time when active young were in turn emerging as progeny of these scales.

On March 15, 1911, a large number of active young were liberated on a small potted orange tree that had first been fumigated and very carefully inspected so that it was absolutely free from any scale. On August 4, 1911, eggs were found under some of these scales which had been liberated $4 \frac{1}{2}$ months before. The scales were very small and were probably stimulated to unusually early oviposition on account of the scarcity of food, as the tree by this time was nearly dead. On August 10, young had commenced to hatch and settle making the period from young to young approximately five months. This experiment verifies what has been observed in the field, namely, that in the case of young scales appearing very early in the spring they are very likely to complete their development before the following winter.

On May 22, 1911, young black scales were liberated on small potted pepper trees out of doors. When examined on September 8, 1911, 8 or 10 scales were found with eggs beneath. Counting the usual hatching period the life cycle in this case would be completed in just four months.

The young hatching from the large spring brood in June and July settle on the leaves largely, where they grow very slowly. Between a month and two months the first molt occurs, and after an interval of about the same length the second molt of the female occurs. This brings it well into the fall, and from that time on migration occurs from the leaves to their permanent abode on the twigs and branches. The winter is passed as a partly grown insect. It has molted twice and is mature, but is still of comparatively small size. With the first period of growth of the citrus tree in the spring, and the rise in temperature, they grow rapidly to full size, and are depositing eggs by the first of May. Those scales, which hatch very early in the spring and have all of the warmer period of the season to hasten their development, will mature in the fall and thus complete their life cycle in a shorter time. The old scales die very soon after their quota of eggs is deposited.

While the above history applies to the great number of scales generally over the citrus belt, there is much variation in certain places as applies to the bulk of the scales as well as to individuals scattered about everywhere, that are out of season with the majority. Their long period of development, through which outside factors have an opportunity to exert their influence, and the congenital differences within themselves, as well as the artificial interference through fumigation must largely account for this variation.

Mortality at Different Seasons. The season of greatest mortality of the black scale is during the summer months, and particularly during the hot weather periods. But the season alone is not responsible, for the stage of the insect is equally as important. It is during the younger 
stages that the great mortality occurs, and this, likewise, is in the summer season. In another place it has been shown that less than 23 per cent succeed in getting established after hatching. Many in our breeding cages died before they reached the first molt and the molting period itself was a critical period when many more died. During the time of development, therefore, or until they have transferred themselves to the twigs, there is much loss by death from one cause or another. After they become fixed on the twigs there is comparatively little loss of life. Such parasites as Aphycus flavus will attack them, and there may be some loss by Coccinellids, but even these prefer the scales in their younger stages. Even Scutellista, which attacks the scale when it is mature, has no effect on the adult scale, for it confines itself very largely to feeding on the eggs.

Annual Progeny of a Single Scale. While the total number of eggs from a single scale may approach 3,000 in number, it is but an exceedingly small per cent that ever reaches maturity. A tree having black scale may become very badly infested in a single year. This is especially true of well cared for citrus trees. It is also a common observation that fumigated trees become reinfested more rapidly than one that has not been fumigated. In many places trees infested with scale have never been fumigated, and the number of insects present seems to remain almost stationary. In such cases the number of the progeny only replaces the number of the adults whose places they have taken. This is true generally of an insect after it has become established. In the case of a new introduction, as, for example, the San Jose scale, Colorado potato beetle, cabbage butterfly, and a host of others, the progeny that matured at first was prodigious. But these insects after a few years, when they become well established, have since maintained themselves in about the same numbers, or, if anything, there has been a slight decrease.

So with the black scale where artificial control is not practiced the actual progeny reaching maturity only replaces the parents. In case of insects where the male is so rare as that of the black scale, this means that only one, or at most two, of the total number of young produced reach maturity. Of course, there may be yearly fluctuations, but for a term of years it will hold true. An effort was made to determine the actual progeny of the black scale under normal conditions. Ten small olive trees were selected and on each of six there was a single black scale, and on the remaining four there were two present on each. These were examined $4 \frac{1}{2}$ and 6 months later with the following result: On tree No. 1 was one scale; on No. 2 no scale aside from the original one; on No. 3 one; No. 4 and 5 two each; No. 6 no new scales; No. 7 three scales; No. 8 two; No. 9 none; No. 10 one. If this experiment were repeated a number of times there would probably be as many variations 
as experiments, but the total together would result very much the same us this single one, namely, that the progeny maturing would be approximately equal to the number of parents that gave them birth.

\section{PARASITES.}

\section{Scutellista cyanea Motsch.}

The most important insect enemy of the black scale in this State is Scutellista cyanea Motsch. It was introduced into the State in 1900 and has since become well distributed in most of the sections where the scale occurs in injurious numbers. The percentage of scales parasitized often runs as high as 75 per cent, but this varies greatly in different sections and in the same section in different years. In 1910 Scutellista was abundant everywhere, but in 1911 it was unusually scarce. The year 1910 seemed to be the summit of one of its regular periods of increase.

\section{HISTORY OF INTRODUCTION.}

In the autumn of 1895 Dr. L. O. Howard ${ }^{1}$ received specimens of what later proved to be Scutellista cyanea Motsch, from Dr. A. Berlese at Portici, Italy. These were bred from Ceroplastes rusci and it at once occurred to Dr. Howard that it would be valuable to introduce the parasite into this country to prey upon Ceroplastes floridensis, an injurious scale in our southern States. It was not until 1898 that specimens were received, and these were sent to Baton Rouge, Louisiana, where they were distributed by Professor H. A. Morgan, as well as in the Insectary at Washington by Dr. Howard himself. Both of these introductions apparently failed.

A year later Mr. C. P. Lounsbury, government entomologist of Cape Colony, found this species parasitic upon Lecanium olece, the common black scale, and sent specimens to Washington for identification. To quote Dr. Howard's own words ${ }^{2}$ : "The past spring Mr. Lounsbury, at the writer's request, made formally through the United States Secretary of Agriculture to the Secretary of Agriculture of Cape Colony, brought with him from Cape Town to New York two boxes of twigs covered with black scale affected with this parasite, and expressed them to Washington, whence they were immediately forwarded to Mr. E. M. Ehrhorn, the horticultural inspector of Santa Clara County, California. On June 19th the writer received a letter from Mr. Ehrhorn announcing the arrival in living and healthy condition of the parasites in question. The twigs in one box were somewhat moldy, but quite a number of parasites were crawling about in the box and were found in the pupal condition in some of the scales. Mr. Ehrhorn had been warned by tele- 
graph and had prepared twenty-five infested oleander plants by potting them and had covered each with a bag of Swiss muslin. In these most of the parasites were liberated and a few allowed to fly in the orchard. Specimens of a hyperparasite (Tetrastichus sp.) also survived the journey, but Mr. Ehrhorn was on the lookout for this parasite and isolated them as they appeared, pending instructions from Washington as to their destruction."

Economic Importance and Present Status in California. In spite of the frequently high parasitization by Scutellista the black scale still remains the most important citrus insect pest in the State. While the number of scales may be considerably reduced through the work of Scutellista, the standard of control required in the commercial citrus crchard, which is clean fruit, is not often attained. This parasite being an egg-feeder, it does not affect the generation of scales attacked. These have done all the injury they would otherwise do, even though they had not been attacked by Scutellista; unless the production of young, and the consequent injury by them, is taken into consideration. Many people realize that the parasite is present and doing good work entirely on the basis of exit holes in the scales. This is, of course, the most conspicuous evidence, and does tell in a general way what is happening. But the real test of what this parasite is accomplishing is to be found in the ability to prevent young from appearing. With the maximum number of exit holes there may still be an abundance of young settled on the leaves. To the casual observer these often escape notice because they are inconspicuous. That this number of young frequently runs high may be indicated by the fact that from 400 to 700 young scales have been counted on each of the leaves arising from twigs that had 75 per cent of the adult scales parasitized. If the efficiency of the parasite in this case was to be judged solely on the number of exit holes it would have been pronounced good, when as a matter of fact it was of very little consequence. It might be said that there would have been just that many more young had it not been for Scutellista; but in this case no more could comfortably settle on the leaves. To follow this case further, six months later there were very few black scales on the tree. They had died during their early development, a good many before the first molt and many more before the second molt. If the young had not been seen on the tree earlier in the season the natural inference, concerning the scarcity of the young scales as compared with the adults, would have been that the Scutellista was responsible.

Such an instance as cited has been observed many times. And the same thing happens where there are practically no Scutcllista. The conc.lusion is forced upon us, therefore, that other factors, aside from this parasite, are at work, and even though the parasite be present in large 
numbers, it does not necessarily follow that it keeps the scale in check. In such cases as mentioned above, the scales were all of large size, and this has an important bearing on the efficiency of Scutellista. Where the scales are small, and the maximum number of eggs produced may not exceed 500, the Scutellista consumes them all, and is a very effective check in reducing the progeny. On the other hand, where from 2,500 to 2,800 eggs are produced there are more than are necessary to bring the Scutellista larvæ to maturity, and so many hatch and give rise to young scales. On shade and ornamental trees the degree of control effected by Scutellista may sometimes be sufficient, but this standard of control is much less likely to satisfy the exacting demands of the commercial citrus grower. But even on such shade trees as the pepper, the infestation often becomes so severe as to warrant spraying, as was generally done in the city of Los Angeles during the past year. While the Scutellista should have full credit for the work it actually does, it should not be counted the one effective agency for the control of the scale whenever or wherever it is not injurious. In Santa Barbara County practically no control work is done against scale insects on citrus trees. In many places in the county the black scale is not injurious. In other places it occurs in abundance, and there is much evidence of sooty mold fungus. The Scutellista is no more abundant there than elsewhere, and is even less abundant where the scales are not injurious. So it is in smaller sections in other parts of the citrus belt.

Distribution of Scutellista. This parasite is generally distributed throughout the citrus belt of southern California. It may oceur much more abundantly at certain times in some groves than others, but if living scales are present and in the proper stage Scutellista will soon be found infesting them. On this account the liberation of a few parasites in a grove will not greatly augment the numbers already present. If there are sections that happen to be free from Scutellista, then artificial introduction will greatly aid them in becoming established. In order that the introduction be effective they should be liberated at a time when the scales are in the proper stage or shortly before. The best season for this will be during May and June. A month earlier or a month later will also find scales in the right stage, but usually in fewer numbers. Scales will be found somewhere in the egg stage at all seasons, but aside from the months mentioned, examination of the particular grove where the introduction is desired should first be made to determine the condition of the scale.

\section{DESCRIPTIONS-LIFE HISTORY-HABITS.}

The Egg. The egg of Scutellista is pearly white in color, oval, more tapering at one end, from which arises an appendage or stalk. The length of the body of the egg is about $.4 \mathrm{~mm}$. and the stalk varies from 
one half to nearly twice that length. The one shown in the figure has a stalk of the extreme length. This stalk is also straighter than others, and there are many gradations from the nearly straight one shown to those having a sharp double curve. The eggs are found beneath the scale either among the eggs of the scale or on the central side of the insect itself if the eggs are not yet present. Eggs have been found both in the field and insectary under scales that had not yet reached the egg-laying stage. Where they are present among the eggs of the scale they can be distinguished from the latter by their slightly larger size and lighter color. The duration of the egg stage during the summer months is from 4 to 6 days.

The Larva. The young larva upon hatching from the egg is very much like the mature larva excepting that it is smaller in size and slightly longer in proportion to the width. The mature larva varies in color from white to gray. The length of the average sized specimens is about $3 \mathrm{~mm}$. and the width $1 \mathrm{~mm}$. It is broadest at the head end while there is a gradual tapering toward the posterior end. The body consists of 14 segments. The head segment is circular, disc shaped, in the center of which is the mouth opening. The external mouth parts consists of a pair of sharp chitinous hooks which are used for piercing the egg shell, or the body wall of the scale itself if eggs are not present. Above and laterad of the mouth on the same segment is a pair of short blunt spines or horns.

The young larva upon hatching soon begins to feed on the eggs of the scale by sucking out their contents, or if eggs are not present it attacks the scale itself. Several instances have been observed where the larva had grown to considerable size under a scale that had not yet laid eggs. It is not, therefore, strictly an egg feeder, as generally supposed, but of course eggs constitute the normal food. Larvæ have been reared from the soft brown scale ( $C$. hesperidum) in which case no eggs at all were consumed, for this scale lays no eggs. Larvæ have also been seen to feed on others of its kind. Cases must occur in nature where several eggs of the parasite are deposited under the same scale, but one, two, sometimes three, and very rarely four, come to maturity. It is possible, therefore, that this cannibalistic habit may occur more or less frequently in nature.

The amount of food consumed or the number of eggs necessary to bring the larva to maturity varies greatly. A scale has not yet been found too small to have a Scutellista pupa. In the case of very small scales it is possible that the larva feeds to some extent on the scale itself. Where the larva appears before the egg-laying period, its attack on the scale may be the cause of the scale being of small size, or of causing it to deposit eggs before it is fully mature. The minimum number of eggs laid by the black scale may be as low as 200 while counts have shown the maximum to run above 2,800 . The size of the mature larva will vary 
greatly in these two cases and likewise the adult. Where the smaller number of eggs occur they are all consumed, but with the larger numbers more than enough is necessary to satisfy the larva, and consequently many hatch.

The full grown larva preliminary to pupation hollows out a cell in the old egg skins and mats these together more or less with a small amount of silk. Strands of silk are frequently, or usually, spun from the inner edge of the scale to the twig, thus insuring the scale remaining fixed during the pupal life of the parasite. It has been frequently cbserved that old scale harboring Scutellista pupa are not lifted from the twig so readily as those not parasitized. Black scale that have thus been parasitized are more likely to remain longer on the tree than those that are not. These may remain on the tree for two or three years in many parts of southern California, where there are no extremes of weather to dislodge them. This fact is not often taken into consideration in estimating the amount of parasitization, so that scales with exit holes increase with each year's infestation, while those without are more likely to drop off.

Length of Larval Life. A larva just hatched was placed in a capsule filled with eggs of the scale on July 19th, and allowed to remain until pupation, which occurred on the 15th day. Others were reared under similar conditions and the larval life was as follows: one larva 16 days; another 17 days; another 20; another 21; and another 17 days. The larval life may thus vary from 15 to 21 days, with an average of about 18 days.

The Pupa. When the pupa is first formed it is white in color like that of the larva. But it soon begins to take on the darker color, and those under observation changed to the jet black in about four hours. The scutellum, eyes, and three small spots on front of head were first to become dark, and later spots appeared on the abdomen. In two hours the whole body had become a very dark gray, tinged in spots with the characteristic metallic black. At this time the parts mentioned above showed blackest, as did also the areas where the wings join the thorax, and the edges of the abdominal segments.

The length of the pupa varies from $1 \frac{1}{2}$ to $3 \mathrm{~mm}$. The large sentellum is conspicuous and extends to the posterior margin of the second abdominal segment. The sheaths enclosing the wings, legs and antennæ are plainly visible on the ventral surface and the whole jet black in color.

Length of Pupal Life. On June 24th a larva pupated and was isolated in the laboratory. The adult emerged in 18 days. Others in the insectary, where conditions were nearly like out of doors, showed little variation. The following records were obtained at different times, but all during the summer months: 3 females in pupal stage 17 days; 
3 females 18 days; 5 males and 6 females 15 days; 8 females 16 days; 2 females 17 days ; 2 males 17 days ; 1 female 16 days; 1 female 19 days ; 3 females 18 days; 1 male and 2 females 19 days; 2 females 17 days; 1 female 20 days. The minimum is thus 15 days and the maximum 20 days. with an average of 18 days for the pupal life.

The most unusual number of pupa found under a single scale is one, but two are commonly found, and more rarely three, while four have been observed twice in many hundred scales lifted. A scale with four of these pupæ is shown in plate V. It will be noticed that each is in a separate cell, with the egg skins held together with silk, dividing them.

\section{THE ADULT SCUTELLISTA.}

The adult is the familiar hump-backed blue fly-like insect which is often seen walking slowly about among the scales. It is strikingly different from any of the other Coccid parasites. The scutellum is very long and extends well toward the tip of the body. The head is broad, set closely into the thorax and is bent under, forming with the scutellum a rounded arch. While the general color is metallic blue, the antennæ and tarsi, excepting the last joint, are usually light brown.

The adult upon transforming to the pupa eats out a circular hole in the dorsal surface of the scale. This operation of eating its way out has nccupied from one to three hours in the cases that were kept under observation. They are in the adult stage from one to three days before emerging. This has been determined by fastening a scale to a cover glass by means of glue, when the transformation to the adult could be cibserved and the time of emergence noted. In lifting scales in the field it will be noticed that occasionally an active adult makes its escape, though no exit hole has been started. After emerging it is not a very active flier and only occasionally indulges in extended flights. It crawls about actively among the scales and when disturbed it jumps or flies for but a short distance.

Oviposition. The eggs are inserted almost invariably under the arch at the posterior tip. The ovipositor is thrust forward and backward two or three times, the egg laid and ovipositor withdrawn, all within about one half minute. The position of the insect in relation to the scale is just opposite that of $A$. diaspidis of the red scale. In the case of the latter the parasite is facing away from the scale, and the ovipositor is inserted by a pushing backward. With Scutellista the insect is facing toward the center of the scale, and the ovipositor is inserted by a pulling of the tip of the abdomen forward. Scutellista have been observed to oviposit within twenty-four hours after emerging. It does not always show the best judgment in selecting scales for oviposition. Oviposition has been noted to occur under the old scales from which all the young had hatched; also under seales already occupied by Scutellista 
larva; under scales where not enough eggs remained to bring the larva to maturity, and where the young had hatched but died before emerging. Eggs have also been deposited under a scale where there was a larva of Rhizobius.

Several eggs may sometimes be laid under the same scale, but this is usually done by different individuals. The same insect will lay several eggs in succession, but different scales are selected for each deposition. In the laboratory a large number of eggs have been obtained under the same scale. Twenty or twenty-five mature females were confined in a test tube with a single partly grown black scale and more than fifty eggs were found beneath it a day or two later. So many were deposited that the scale was lifted from the twig. In such a case they were inserted at other points than the arch at the posterior end. But it will be noted upon consulting plate II that even here the majority were inserted at the posterior end. Oviposition has been noted to occur naturally in the field under scales that had not yet reached the egglaying stage. In the insectary the youngest scales chosen were those that had recently molted the second time. They were thus mature, but were still very small and would not normally deposit eggs for several months later. But this was under forced conditions, and such young scales would probably not be selected in the field. Young scales previous to the second molt were not chosen even under forced conditions. About 50 female Scutellista were confined in a tube enclosing an oleander leaf on which were black scales about one month old. A day or two later an examination of the scales failed to reveal any eggs having been deposited. On a check experiment with mature scales eggs were oviposited under freely.

Proportion of the Sexes. In a considerable number of specimens collected at different times the number of males and females do not vary greatly, but in general the males are slightly in the majority. This seems to be especially true where the scales themselves are small. The size of the Scutellista varies greatly and this is dependent upon the food supply. The males are, of course, smaller than the females, but whether the food supply has any influence on sex determination is a debatable subject, with the greater amount of more recent evidence against it.

Parthenogenesis. While males are nearly always present in equal or even larger numbers than females, reproduction is apparently able to occur without the males, according to the following experiment. Mature black scales with eggs were allowed to remain a week under cover in order to allow any chance for Scutellista eggs that might be present to hatch. In the mean time several pupæ were put each in a separate box and the adults allowed to mature. Two of these unfertilized females were placed in a vial containing a twig infested with a single black scale. Seven days later the scale was lifted and two Scutel- 
lista eggs and four larvæ were found. Since the eggs hatch in from four to six days the larvæ and eggs present must have come from those liberated.

Length of Adult Life. A young orange tree badly infested with black scale was placed in a screen cage and several Scutellista of both sexes, which had just emerged, were liberated. The conditions were as nearly natural as possible, there being ample opportunity for oviposition, or for feeding, if necessary. The length of life under these conditions was 10 to 15 days. Others which had recently emerged were confined in pill boxes without food. The length of life was about the same as under the above conditions.

By spraying sweetened water on scale infested twigs in the laboratory Mr. P. II. Timberlake and Mr. Rust have succeeded in keeping the adults alive for from 23 to 51 days.

\section{SEASONAL HISTORY OF SCUTELLISTA.}

The stages and abundance of Scutellista are very much dependent upon the same conditions in its host. Since the black scale is at the height of egg laying in June, it is then that Scutellista larva will be most abundant. The pupal period follows this and July will usually be the period of greatest emergence of adults. While in June and July the various stages of Scutellista are most abundant, it will be found to a less extent in all stages at all other seasons. Just as there are scales out of season so there are of their parasites. But during the off season the Scutellista, like the scales, may not be found in the same grove. They may be on other trees than citrus, such as pepper, olive, or oleander, or they may be on citrus trees in a different section, or even a different grove, where conditions may be more or less different.

\section{NUMBER OF GENERATIONS.}

Here again the scale determines largely the number of generations. If there were a uniform hatch of the scale occurring during the spring and no more scales matured until the same time next year, there would be but one generation of Scutellista. Since, however, some scales may be found in all stages at all seasons, the Scutellista is permitted to go through several generations. The number will thus vary, but when the scales are in the right stage the number can be calculated from the length of life cycle. One record from egg to adult will indicate the length of life and the duration of the different stages.

Egg laid July 22d; hatched July 27th; pupated August 12th; adult emerged August 26th; adult died September 4th. The egg period is thus 5 days, larval 16, pupal 15, adult 9, or a total of 45 days from the egg to the death of the adult. Another completed its life cycle in 43 days; another in 45 days; another in 50 days; another in 48 days; 
another in 44 days; another in 46 days, and another in 50 days. On this basis there would be 4 generations from May to October, inclusive. From November to April, on account of the slower development during the winter months there will be from 2 to 3 . While there may be thus a total of 6 or 7 generations a year, on account of the unfavorable condition of the host, 4 or 5 will be nearer the actual number.

\section{HYPERPARASITE. \\ Cerchysius sp.}

Under the old black scales there will be occasionally found, instead of the characteristic Scutellista pupa, a black or brown oval or torpedoshaped body that may at first be mistaken for a dipterous puparium. This will be found to be the old larval skin of the Scutellista larva distended and harboring a parasite within this parasite. This has been taken from several different sections, including Whittier, Glendale. Pomona, Santa Paula, and Santa Barbara. But it is found most abundantly at Santa Barbara, where in certain groves the percentage of $S$ cutellista attacked ran between 5 and 10 per cent.

\section{THE LARVA.}

The larva of this hyperparasite is white in color, length $2 \mathrm{~mm}$., greatest width nearly $1 \mathrm{~mm}$., 13 segments, broadest at head end and

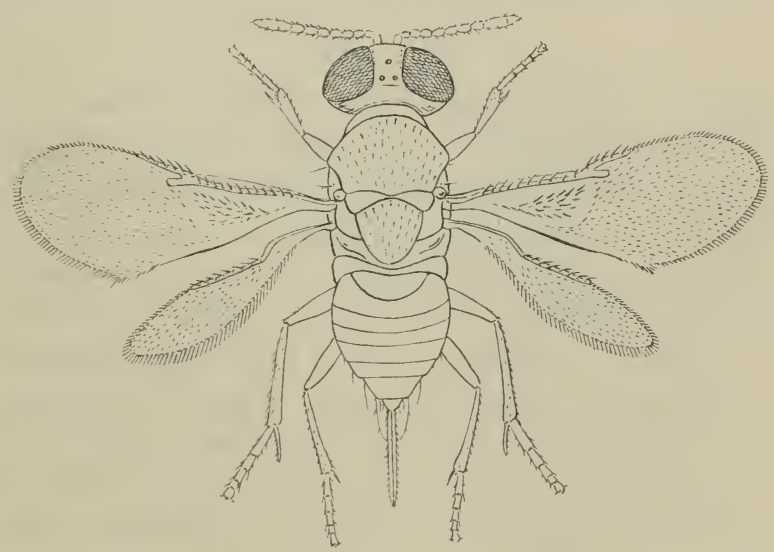

Frg. 12.-Hyperparasite on the Scutellista, Cerchysius sp.

gradually tapering toward the posterior. Very similar in color and shape to that of its host. On the head segment of the larva of Scutellista there is present above, and laterad of the mouth, two blunt horns or spines. These are absent on the larva of Cerchysius. This larva completely consumes the contents of the Scutellista larva, leaving only the outside epidermis. This is changed to a leathery texture, and to a dark 
brown or black color. Preparatory to pupation the meconia are voided, and these are to be found compressed into one end of the larval skin of the host. Scutellista larvæ attacked by its parasite, and having the characteristic appearance as though the parasite within was in the pupal stage, were collected on October 29th, and upon removing the covering on December 31st the hyperparasites were present as full grown healthy larvæ. From this it would appear that the full grown larva must pass through a period of hibernation, or else the effect on the host is made cvident very early, or at the beginning of the attack by the parasite. Nearly all the host larvæ were full grown when they took on the characteristic appearance of parasitized larvæ, but a few have been taken when they were but one half grown. Occasionally the host manages to change at least partially to the pupa. In such cases certain characters of the pupa appear, as the constriction at the head, the large scutellum and the outline of the abdomen, but there are practically no indications of appendages or other characters of the true pupa. Specimens from which the parasite appeared ready to emerge, which were collected in October, were still in the larval condition in January, indicating that the winter or at least a portion of the winter is passed as a full grown larva.

The pupa appears to change within its old larval skin, as shown in plate VI. This was removed from a parasitized Scutellista larva at the same time that the full grown larvæ were taken.

\section{THE ADULT.}

Length $1 \frac{1}{2} \mathrm{~mm}$.; wing expanse $3 \mathrm{~mm}$. Head and thorax finely reticulate and covered with fine black hairs. Entire body black, with greenish iridescence; front leggs entirely black; middle femur with band of light brown at proximal one third, lighter color at tip of femur, and greater area at tip of tibia; middle tarsi light brown. Hind legs entirely black; tibial spurs present, middle ones largest. Tarsi 5 jointed. Antennæ 10 segmented, pedicel widened in center and twice as long as first segment; joint 3 equal to 1, remaining joints of equal length, excepting last. This segment, which is club-like, is divided into three divisions. The segments, excepting first two, are covered with many hairs nearly equal in length to that of the segment. Wings not fringed or with very short hairs. Sub-marginal vein strong and with row of conspicuous spines.

When the adult is ready to emerge a cap or portion of one end of the larval skin of the Scutellista is broken off and after emerging from this eats out a circular hole in the dorsum of the scale similar to the Scutellista. excepting that they appear very slightly smaller on the average. 


\section{Tomocera Californica How.}

This is another egg parasite of the black scale, and formerly was as abundant as Scutellista is to-day. In 1880 Professor Comstock stated that "upon more than one tree at least 75 per cent of the scales appeared to be parasitized. In no locality was the black scale found without this attendant destroyer." During the past three years this same parasite has been but occasionally met with. So scarce has it been that we have not secured enough material to make it worth while undertaking life history studies. It seems to be most abundant at present in Santa Barbara County and possibly were we on the grounds there some material might have been available for life history work. What has changed this from a very abundant parasite to one only rarely met with is difficult to account for. It would involve a thorough study of the inter-relations of all the factors bearing on the subject. Again, some definite and specific cause, such as the usurping of the field by Scutellista, might account for it. What was true regarding the abundance of Tomocera in 1880 was true for Scutellista in 1910.

\section{DESCRIPTIONS AND LIFE HISTORY.}

According to Comstock the female pierces the body of the scale and leposits probably but a single egg. It is more likely that, like Scutellista, the ovipositor is inserted between the scale and the twig. The mature black scale, with its tough, leathery surface, would not be easily penetrated by the ovipositor, and it might also result in injury to the scale.

The larva feeds upon the eggs and young, and to some extent on the scale itself if eggs are not present. When full grown it is about $4 \mathrm{~mm}$. long, broad, spindle shaped, somewhat more pointed at the anterior than the posterior end of the body. Its

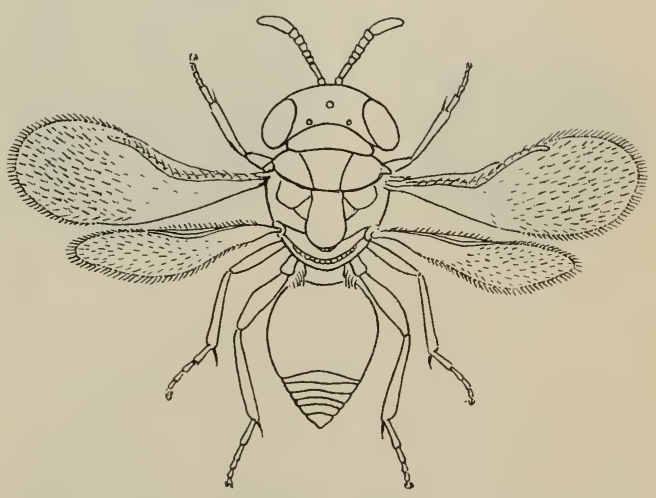

FIG. 13.-Tomocera californica How. From Report U. S. D. Agr. for 1880 .

color is clear white, the contents of the alimentary canal often showing through, giving it a blackish tinge. This larva transforms to a whitish pupa which soon turns black, in this respect again being similar to Scutellista. The same sort of an exit hole and of the same size is made in the scale.

The adult, in general color, is a metallic blue black insect. Enough of 
Howard's original deseription ${ }^{1}$ is given herewith to enable identification. Length of body $2.1 \mathrm{~mm}$.; wing expanse $3.5 \mathrm{~mm}$.; abdomen subovate, first segment large. On each side of the peduncle on the anterior part of the first abdominal segment is a strong tuft of snow white hairs. Head, face, scape of antennæ, and under side of all legs, light mahogany brown. Thorax black with a strong metallic luster on prothorax, tip of scutellum and scapulæ, abdomen bluish black with a slight brownish patch beneath at the base. Tarsi 5 jointed. The center of the forewing is occupied by a large dusky patch.

\section{Aphycus Flavus How.}

Aphycus flavus How. is parasitic upon the male black scale. Specimens of this parasite have been taken at Whittier, Glendale, Pomona, and San Diego. It attacks the male scale in the second stage and is strictly an internal parasite. It also attacks the female at about the time for the second inolt.

The larva is a small, white, grub-like creature, measuring when full grown about $1 \mathrm{~mm}$. long and $\frac{1}{2} \mathrm{~mm}$. broad. It is the broadest near the

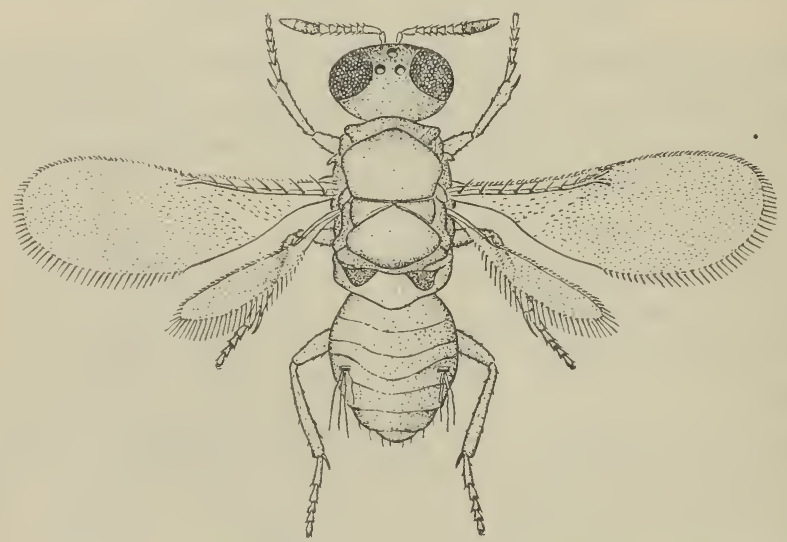

Fig. 14.-Aphycus flavus How. parasite of soft brown and other scales. $\mathrm{x} 40$.

head end and tapers gradually toward the posterior end. The mandibles are very broad and stout, abruptly tapering into a sharp, slightly curved hook. The curved tip will distinguish it from the larva of 1. diaspidis.

The pupa is darker in color, having changed from the white color of the larva. Its length is $8 \mathrm{~mm}$. and greatest width $\frac{1}{2} \mathrm{~mm}$. The eyes are red.

The Adult. Length $1.2 \mathrm{~mm}$; wing expanse $2 \mathrm{~mm}$. ; color dark yellow; abdomen darker; eyes reddish black; antennæ scape with dusky patch

${ }^{2}$ U. S. D. A. Report, 1880 , p. 368. 
above; wings clear; veins yellowish; antennæ 11 jointed; pedicel about twice as long as thick. The club is as long as the three preceding joints.

\section{OTHER PARASITES.}

Aside from those already mentioned, Coccophagus lecanii and $C$. lunulatus have been reared from the partly grown scales. But all of these internal parasites are very scarce as compared with the egg-feeding parasites.

According to Mr. C. P. Lounsbury, the following parasites have been reared from the black scale by Mr. C. W. Mally in South Africa:

Scutellista cyanea Motsch.

Coccophagus orientalis How.

Microterys sp.

Microterys sp.

Coccophagus, near ochraceus How.

Aphycus lounsburyi How.

Tetrastichus sp.

Tetrastichus sp.

Coccophagus.

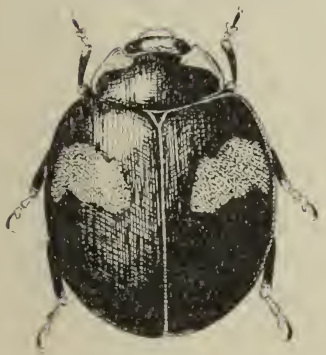

1.

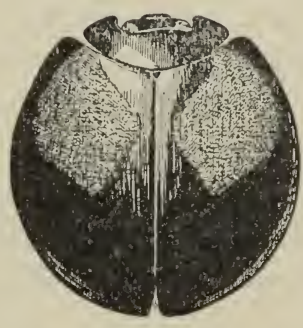

2.

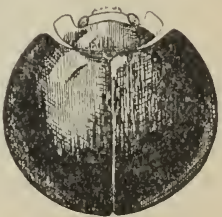

3.
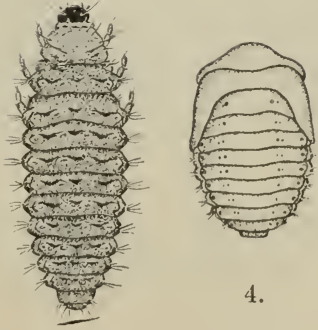

4.

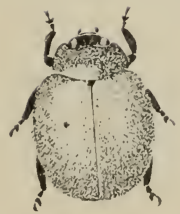

FIG. 15.-Coccinellids feeding on the Black Scale. $x \tilde{y}$

1. Olla plagiata Casey.

2. Axion plagiatom Casey.

3. Orcus chalybeus Boisd.

4. Larva, pupa and adult Rhizobius ventralis Black. 


\section{PREDACEOUS ENEMIES OF THE BLACK SCALE.}

\section{Rhizobius ventralis.}

The commonest and most characteristic Coccinellid attacking the black scale is Rhizobius ventralis. The larva feeds on the eggs, the young that have not emerged from beneath the parent, and the younger stages of the insect after it has settled. On account of its firm leathery covering, the adult is seldom attacked by this beetle.

The egg is pearly white in color and oval in shape. Its length is .8 of a millimeter and its width $.4 \mathrm{~mm}$. They are found under the scale. Plate II, figure 3 shows five such eggs in their natural position beneath the black scale. Eggs are not laid here exclusively, for this beetle feeds on other insects than the black scale. And sometimes even with this scale eggs may be deposited elsewhere, but they are very commonly found under the scale.

The Larva. Length $5 \mathrm{~mm}$; width $1 \frac{1}{2} \mathrm{~mm}$.; upper surface entirely black; prothorax segment surrounded on margins, except posterior, with a row of long hairs, those laterally arising from prominences. A row of short inconspicuous hairs on either side of the dorsal line, two hairs in a place, papillæ scarcely visible. Another row slightly more than one half way to lateral margin, from two to five hairs on each segment, and arising from prominent papillæ. Another row slightly below lateral margin with six hairs in a place arising from very conspicuous protuberances. Ventral surface dirty gray with legs darker in color.

The larva hatching from those eggs laid under the scale begin to feed on the scale, or the eggs, or young. In case the scale is in the egg-laying stage they may grow to considerable size under the same scale, and wander about attacking many different scales. It is in this stage that the most feeding is done and consequently is most efficient as an enemy of the scale.

The Adult is broadly oval in shape, measuring about $3 \mathrm{~mm}$. long. Thorax and elytra shining black and covered with gray hairs. The surface is finely punctuate; ventral side of head and thorax black. Abdomen distinctly brown. Legs black, excepting the tarsi, which are brown. 


\section{OTHER PREDACEOUS ENEMIES.}

Orcus chalybeus.

This is the steel blue beetle that is found commonly on citrus trees, particularly in Santa Barbara County. It has been more frequently met with on black scale infested trees than any others.

Several other species of Coccinellids have been taken from black scale infested trees, including Hippodamia convergens, Coccinella californica, Chilocorus bivulnerus, and Axion plagiatom.
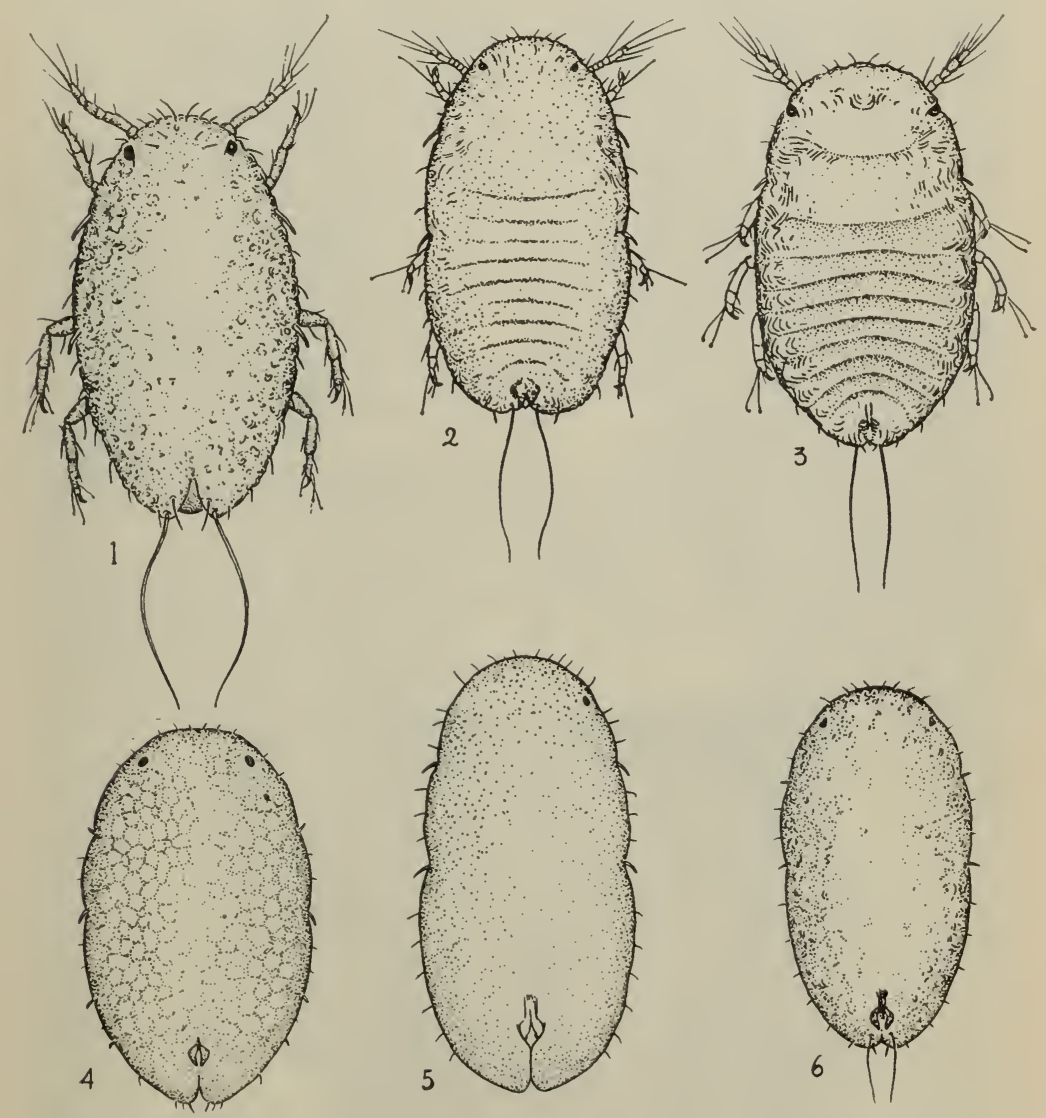

Fig, 16.-First and second stages of some unarmored scale insects.

1 and 4. Saissetia oleae Bern.

2 and 5 . Coccus hesperidum Linn.

3 and 6 . Lecanium corni Bouchê. 


\section{OTHER SPECIES OF UNARMORED SCALES ASSOCIATED WITH THE BLACK SCALE.}

\section{Hemispherical Scale.}

(Saissetia hemispharica Targ.)

This only rarely becomes troublesome on citrus trees, but occurs commonly on ormamental and greenhouse plants. Its lighter color, glossy surface, smaller size, and the absence of the letter $\mathrm{H}$ will readily distinguish it from the black scale. The common parasites are Comys fusca and Coccophagus lecanii.

\section{Soft Brown Scale.}

\section{(Coccus hesperidum Linn.)}

This scale frequently attacks citrus fruit and a few trees or parts of trees are often badly infested. Its flatness and lighter color distinguish it at once from the black. The earlier stages, however, resemble the black very closely. Some of the differences are shown in the accompanying figures. Aplycus flavus, En-

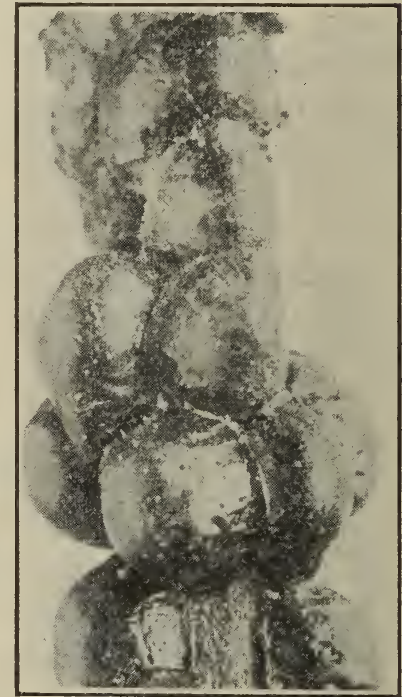

FIG. 17.-Hemispherical Scale on twig of orange. cyrtus flavus, Coccophagus lecanii, and Coccophagus lunulatus are the common parasites of this scale.

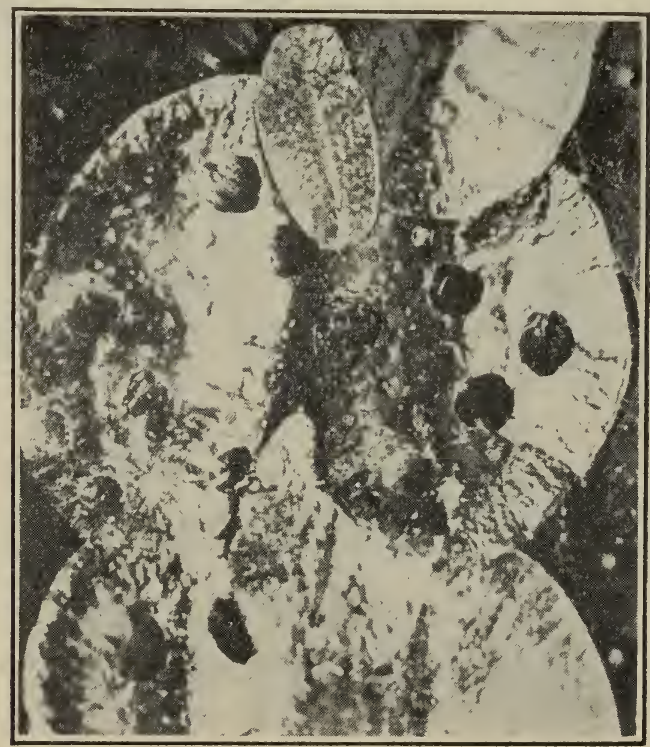

FIG. 18.- Soft brown scales with exit holes of Aphycus flavus. 


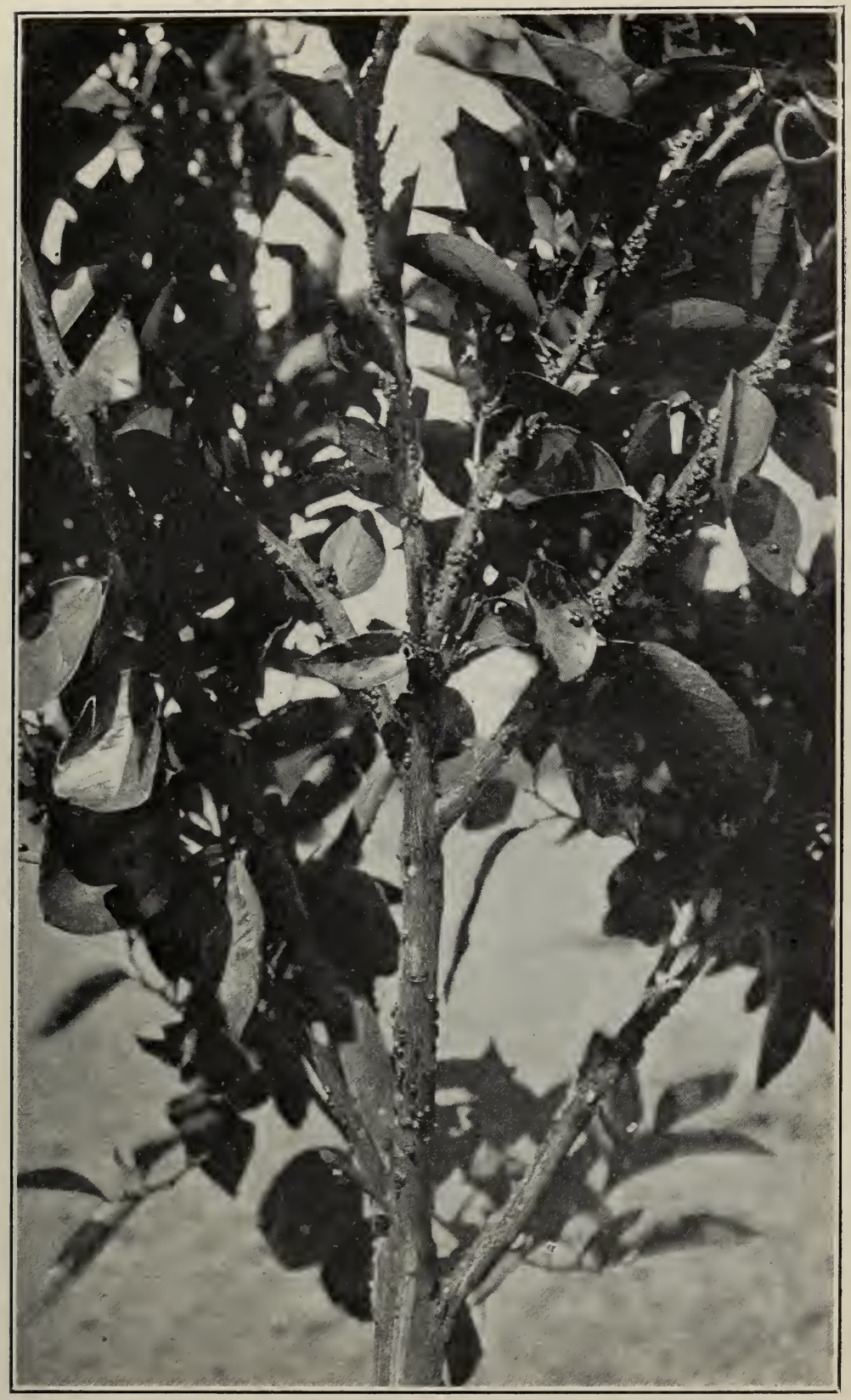

Pi.ATe I.

Photograph of small orange tree in the field showing Black Scale on trunk and branches. 


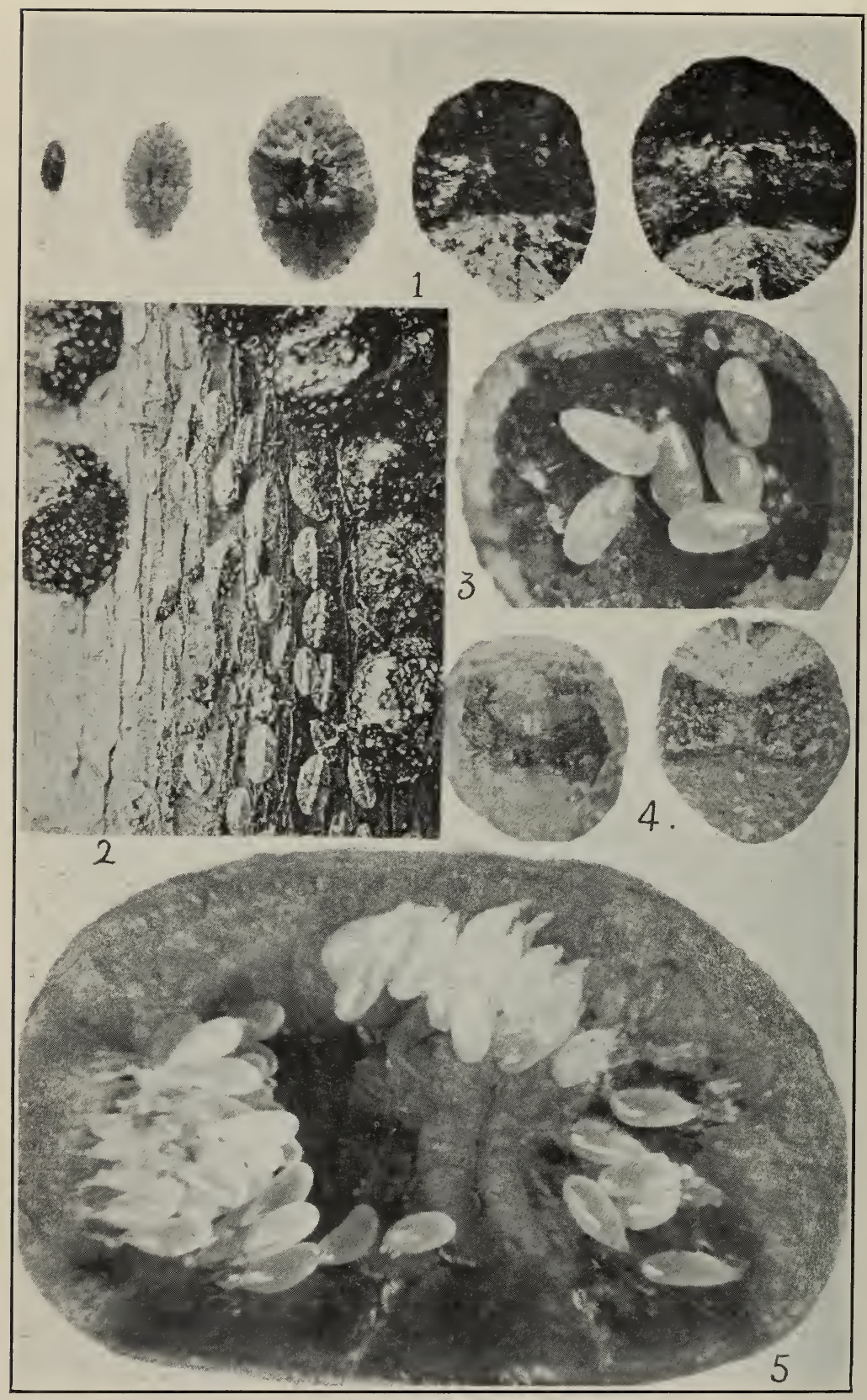

Plate II.

1. Different stages of Black Scale.

2. Young Black Scale shortly after settling.

?. Eggs of Rhizobius ventralis under Black Scale. $\mathrm{x} 17$.

4. Hemispherical scale on left and black of same size on right.

5. Inverted Black Scale with 50 eggs of Scutellista. x30. 


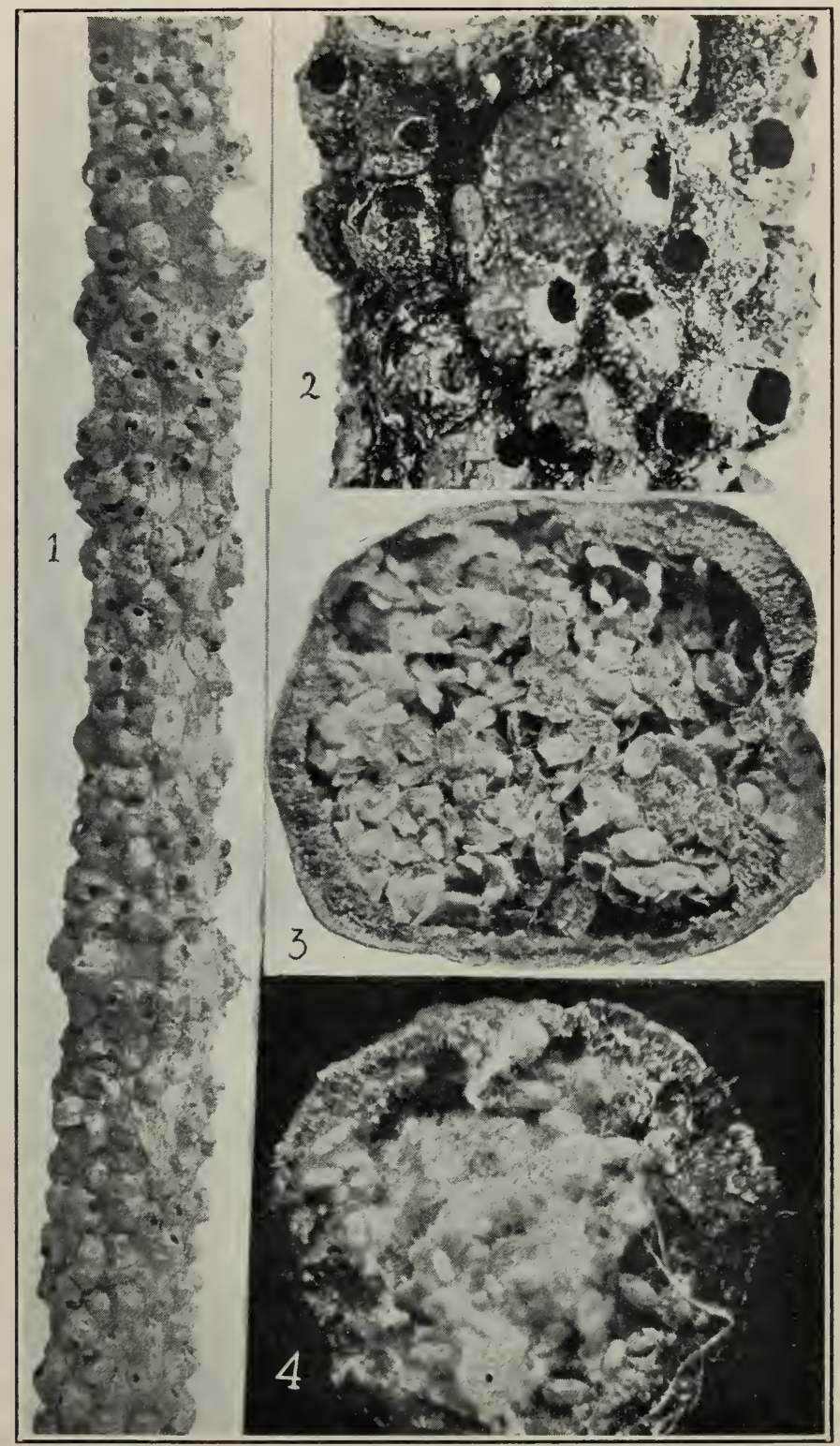

Plate III.

1. Black scale with exit holes of Scutellista.

2. Portion of same more enlarged.

3. Young black scale hatched but died before emerging.

4. Eggs and young scales killed by fungus, Isaria. 


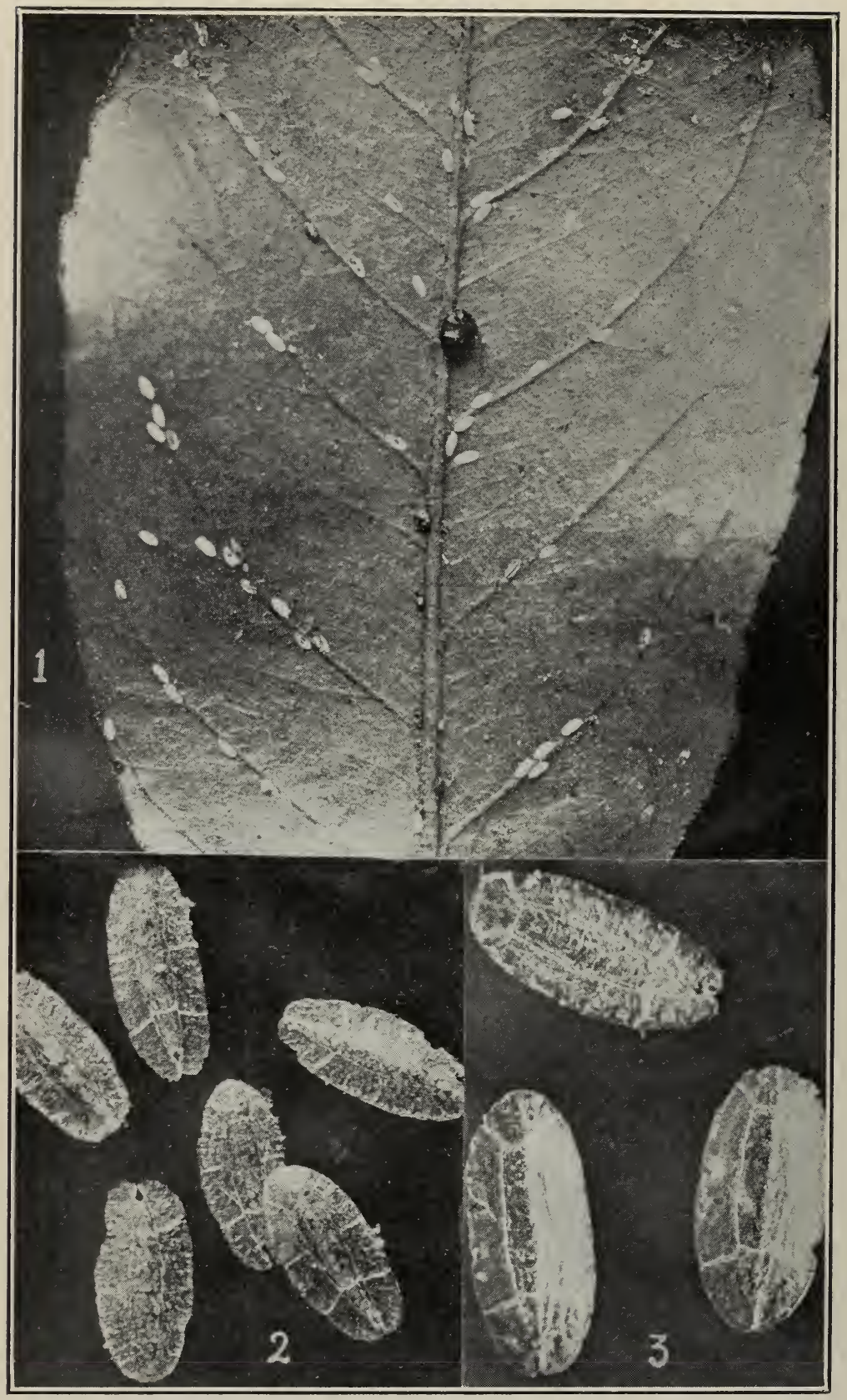

Plate IV.

1. Male puparia of Black Scale. $\times 1 \frac{1}{2}$.

2. Same enlarged. x18.

3. Puparia of Hemisphærical Scale. Same magnification as 2. 


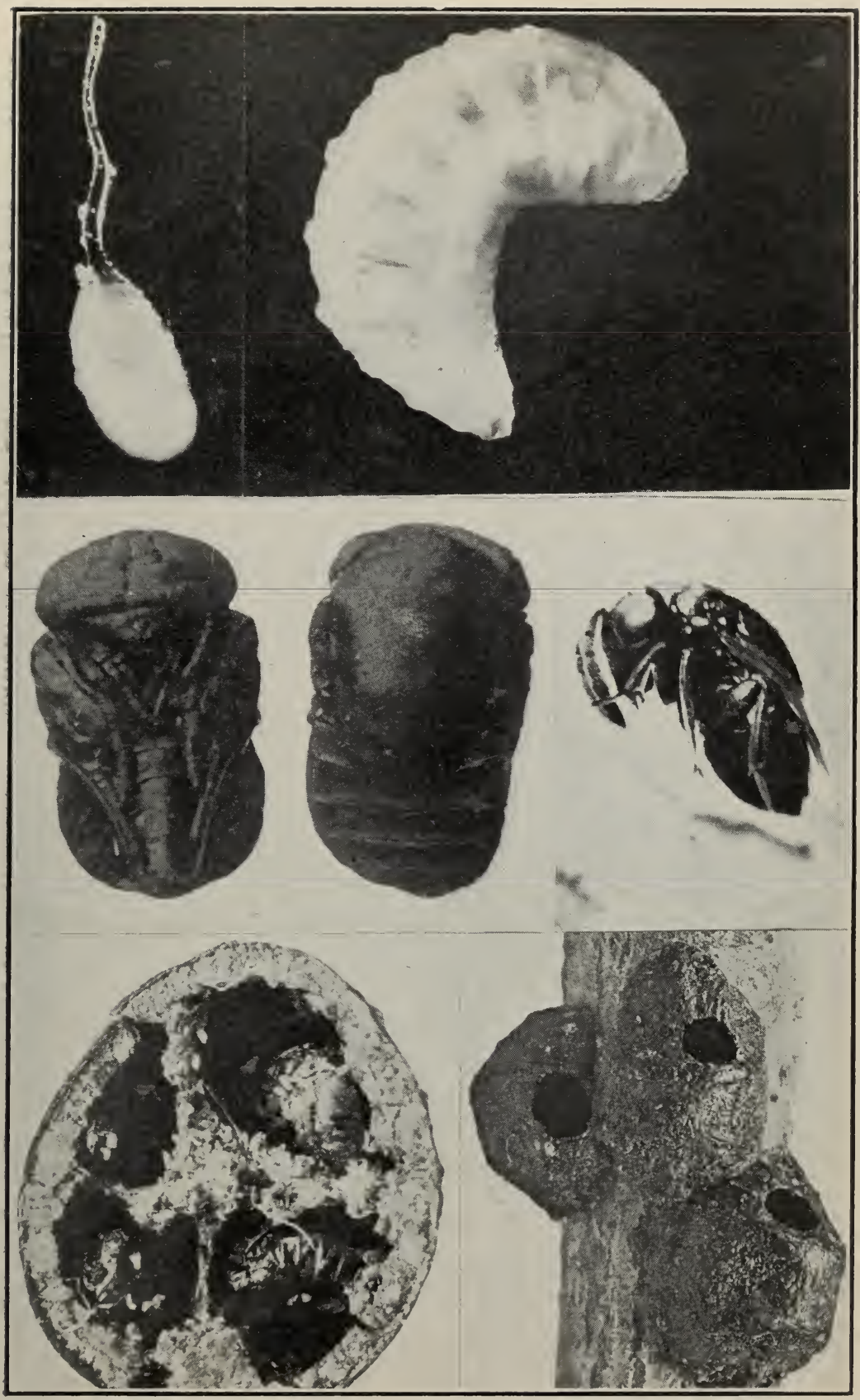

Plate V.

Scutellista cyanea Motsch, egg $\times 70$; larva $\times 25$; pupæ, ventral and dorsal views $\times 20$; adult $\times 17$; inverted Black Scale showing four pupæ; exit holes in scales. 


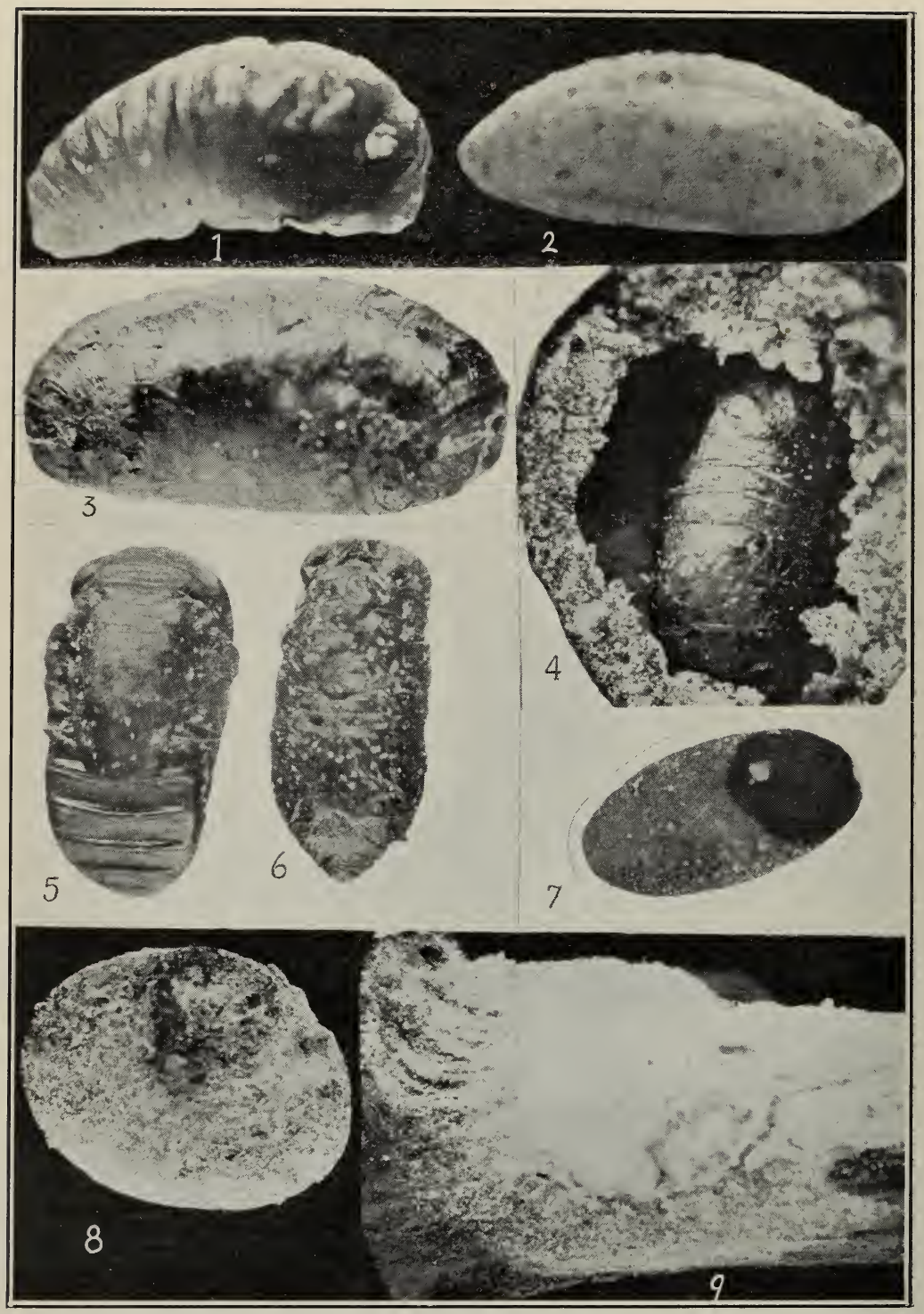

Plate Vi.

1. Larva of Scutellista parasite, Cerchysius sp. $\times 25$.

2. Larva of Cerchysius partly changed to pupa. $\mathrm{x} 25$.

3. Parasitized larva of Scutellista harboring Cerchysius within. $\mathrm{x} 25$.

4. Appearance of parasitized Scutellista larva beneath scale. $x 25$.

5. Normal Scutellista pupa. $\times 20$.

6. Parasitized Scutellista pupa or Scutellista larva which succeeded in partly changing to pupa. $\times 20$.

7. Exit hole of parasite in old larval skin of Scutellista.

8. Black scale killed by fungus, Isaria.

9. Fungus covering scale and spreading over twig. 


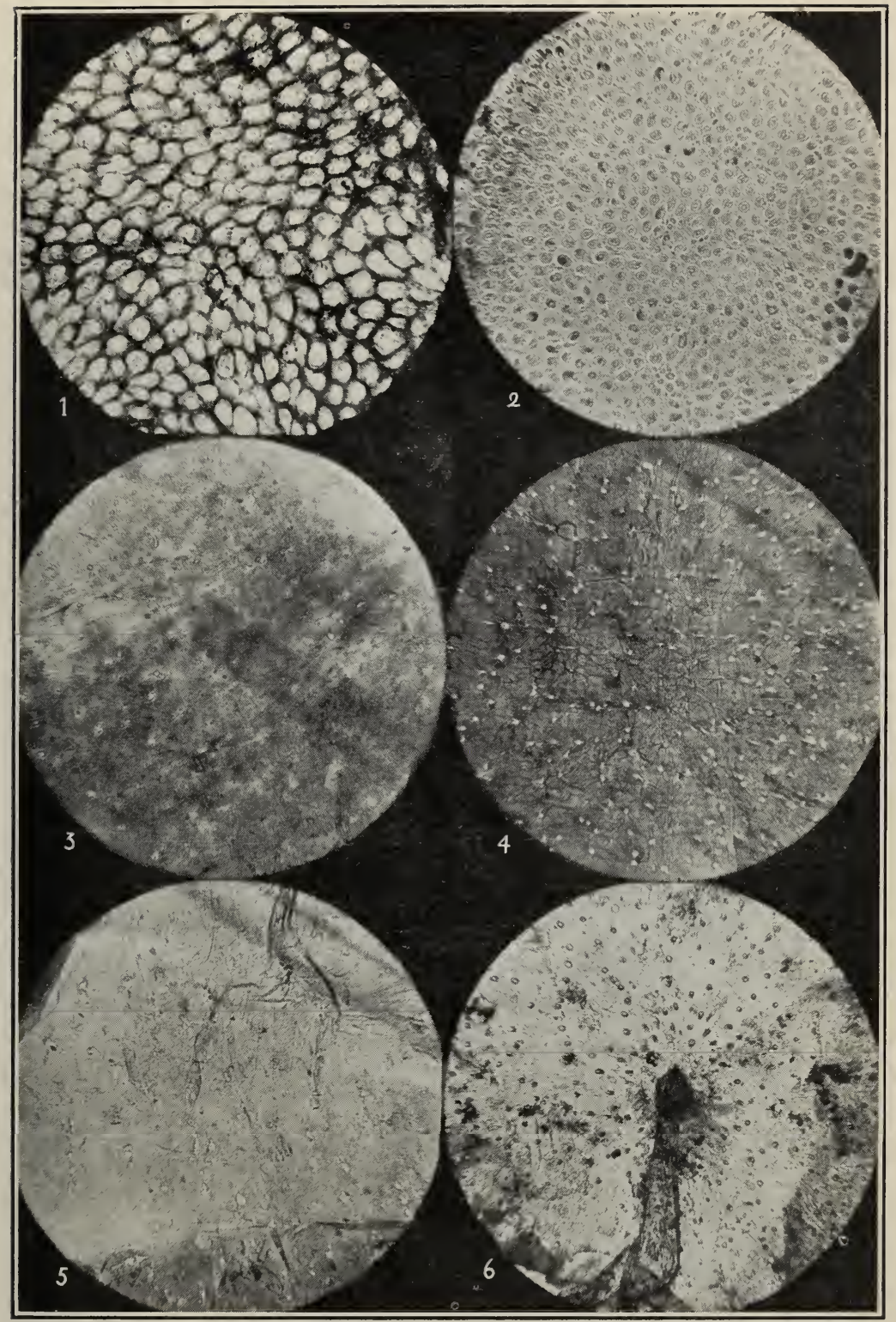

Plate VII.

Photomicrographs of derm pores. $\mathrm{x} 50$.

1. Saissetia oleae Bern.

2. Saissetia hemisphærica Targ.

3. Lecanium corni Bouché.

4. Lecanium pruinosum Craw.

5. Lecanium sp. on Heteromeles.

6. Coccus hesperidum Linn. 


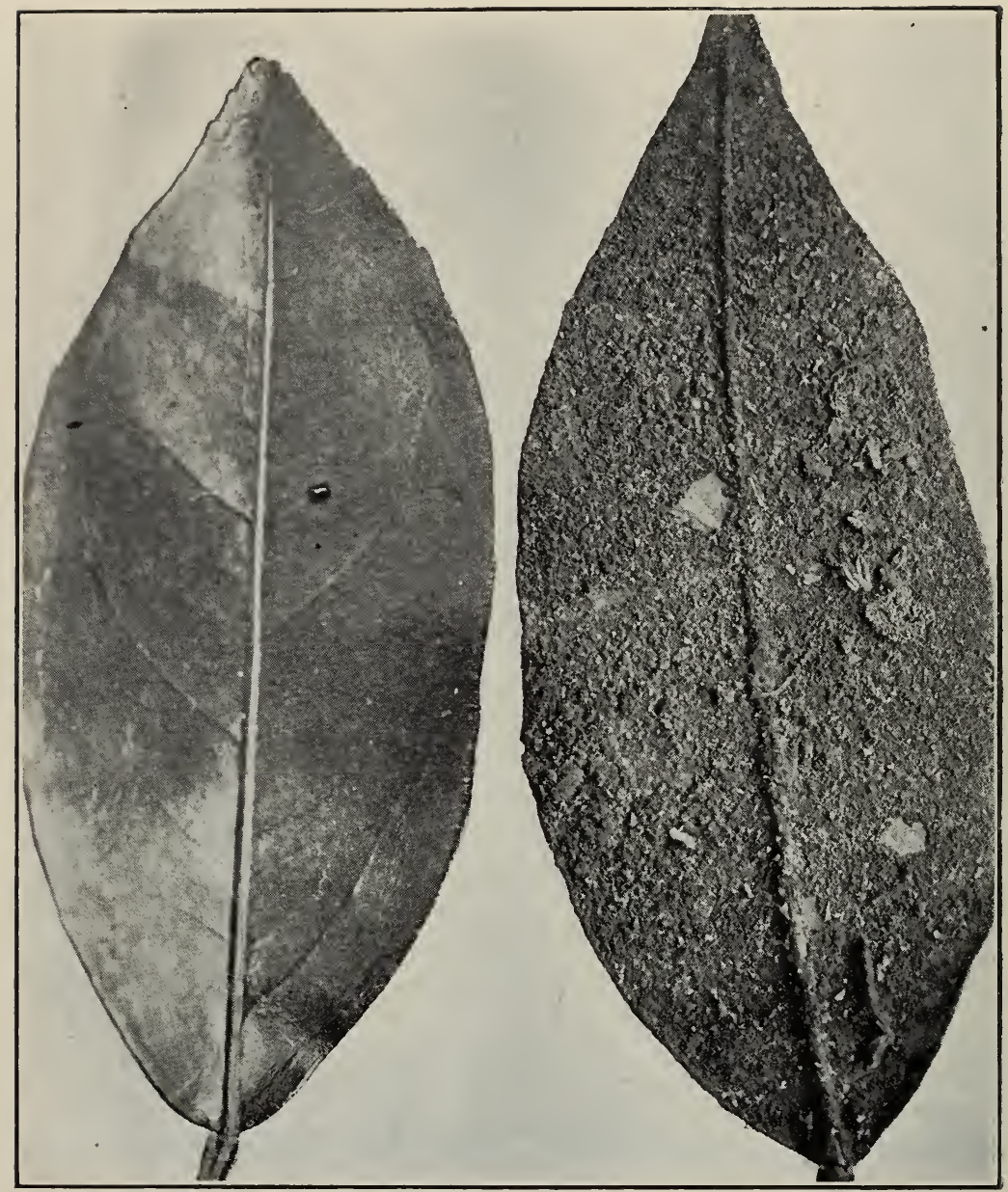

Leaf on right showing sooty mold fungus as a result of Black scale infestation. Normal leaf on left.

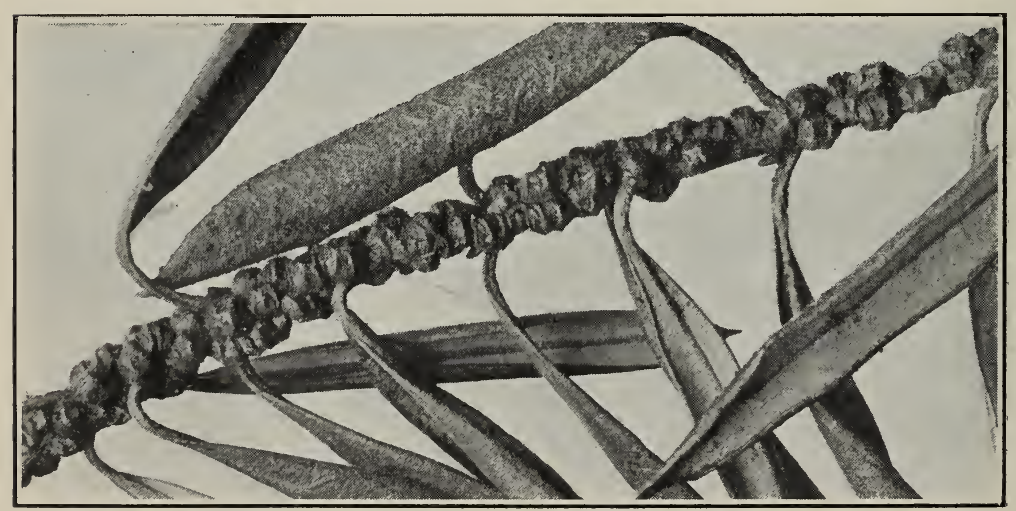

Saissetia oleæ on Olive.

Plate VIII. 


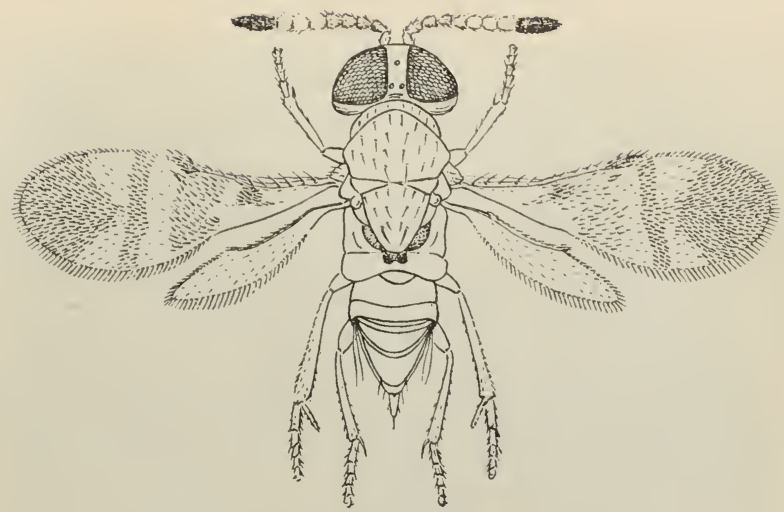

Fig. 19.-Encyrtus flavus How. $q \times 25$.

\section{European Fruit Lecanium.}

(Lecanium corni Bouché.)

This is what has been called the brown apricot scale in this State and went by the scientific name of Eulecanium armeniacum Craw. Professor J. G. Sanders ${ }^{1}$ in a recent study of the Lecanium group places it

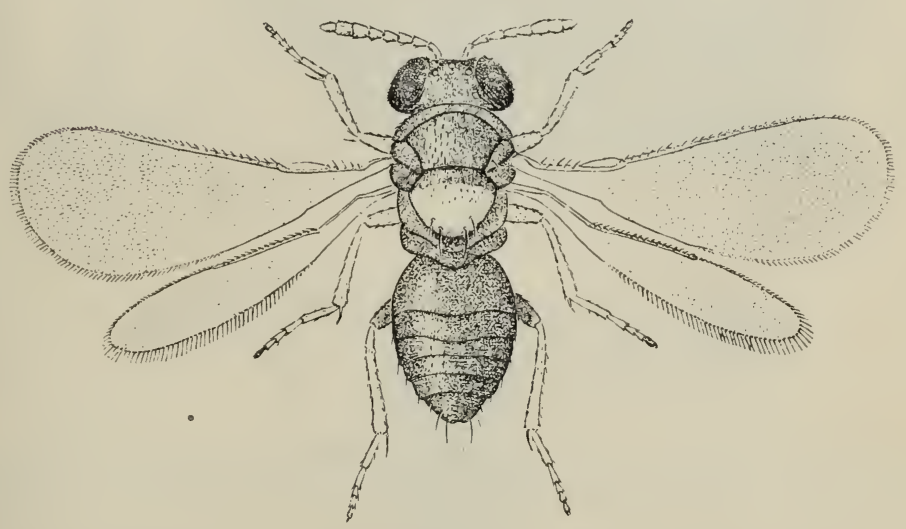

FIG. 20.-Coccophagus lunulatus How., parasite of soft brown and other scales.

under the name given above. This scale does not occur on citrus trees, so far as we have seen, but is frequently associated with the black on prune, apricot and other deciduous trees. Comys fusca is the commonest parasite and is widely distributed.

${ }^{1}$ Jour. Ec. Ent., vol. 2, No. 6, p. 443. 

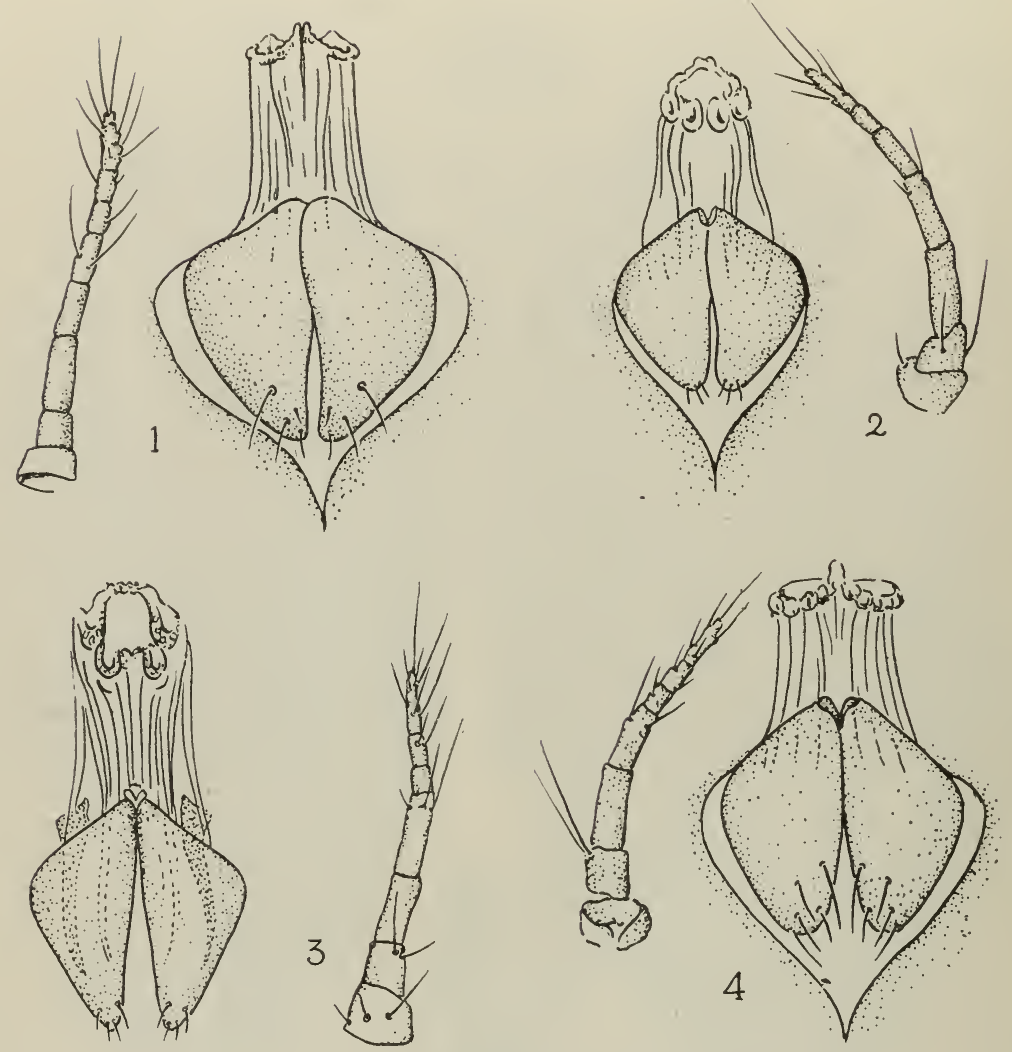

F'IG. 21.-Antennæ and anal lobes.

1. Saissetia oleae Bern.

2. Lecanium pruinosum Coq

3. Coccus hesperidum Linn.

4. Lecanium corni Bouché.

The Frosted Scale.

\section{(Lecanium pruinosum Coq.)}

This scale is very similar to $L$. corni and frequently occurs with it as well as with the black. It is usually considerably larger than corni and is covered with pruinose, hence the name. In southern California it not infrequently occurs on the English walnut. Comys fusca has also been reared from this scale.

\section{Lecanium sp.}

This scale occurs very commonly on the Christmas berry Heteromeles. It was at first mistaken for the Hemispherical scale, but typical specimens appear much larger and slightly different in shape. Upon drying they are also inclined to shrivel, as indicated in the figure. It is very 


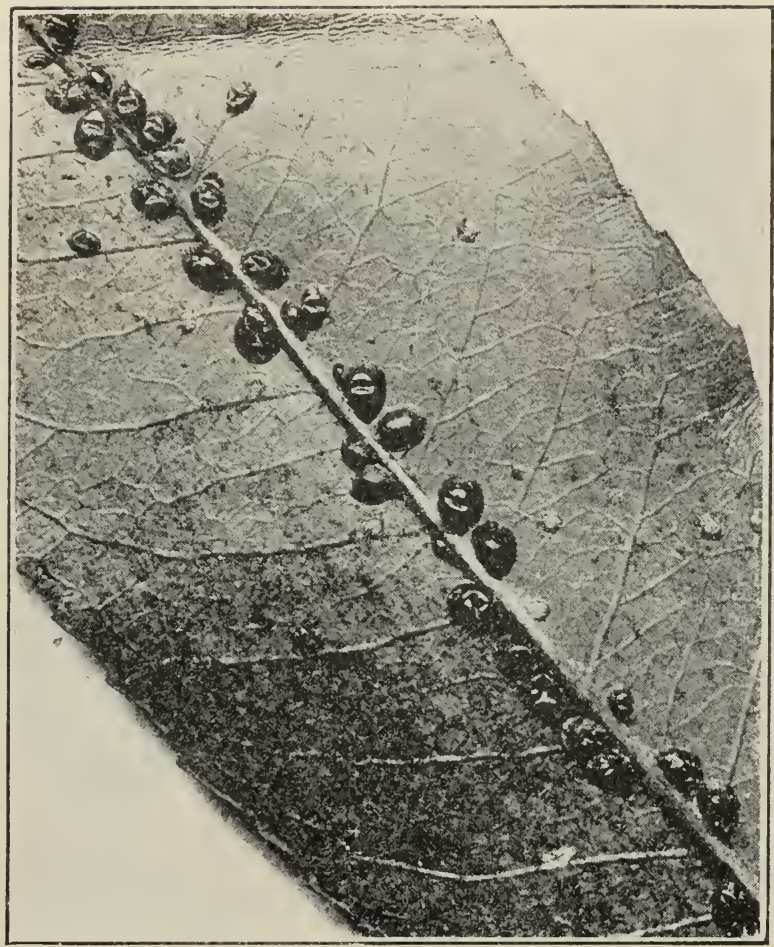

FIG. 22.-Lecanium sp. on Heteromeles.

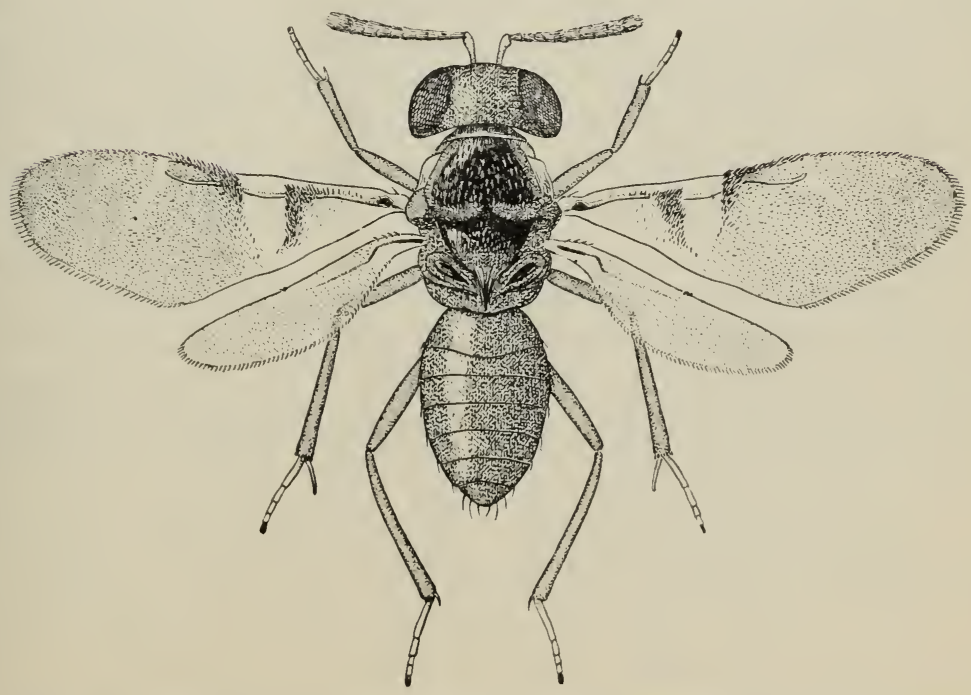

FIG. 23.-Comys fusca How., parasite on Hemispherical, Brown Apricot, and other scales. x18. 
heavily parasitized by Comys fusca and to a less extent by Coccophagus lecanii. The former attacks only the larger scales, and since these come to maturity in May and June this is the time when most of the parasites emerge. Seales attacked by C. fusca do not lay eggs. While C. lecanii usually attack the smaller seales, not infrequently the larger ones are also chosen. One or two of these parasites may mature in the scale and yet eggs will be deposited by the scale.
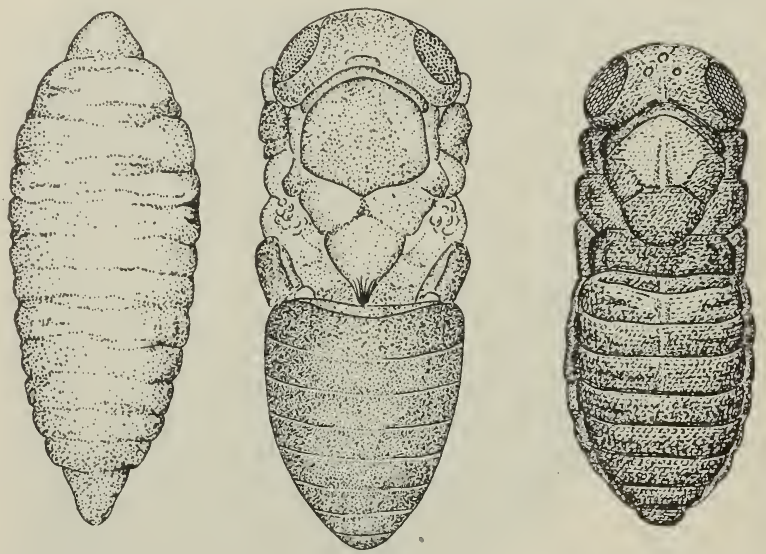

Fig. 24.-1. Larva of Comys fusca. 2. Pupa of Comys fusca. 3. Pupa of Coccophaguis lunulatus.

\section{SYSTEMATIC POSITION AND RELATIONSHIPS.}

Saissetia oleae Bern. belongs to the subfamily Coccince, of the family Coccida, which is characterized by the possession of triangular supraanal plates. This species is readily recognized by a median longitudinal carina and two transverse carinæ forming the characteristic H. Other species of the genus recorded from California are: filicum Bvd., hemispharica Targ., and nigra Mitn. Aside from hemisphcerica these species are limited to a greenhouse locality and are of no particular importance. The species olea was first described under the genus Chermes. A few years later it was placed under the genus Coccus. In 1852 the name Iecanium was given for the genus and for a long while it was thus known by various writers until it was changed by Professor Cockerell to Saissetia in 1901. 


\section{BIBLIOGRAPHY.}

Up to 1903, the bibliography of Saissetia oleae is given in Fernald's Coccidæ of the World. The following includes the references to this insect since 1903, which has been furnished through the courtesy of Mr. E. R. Saccer, of the Bureau of Entomology, Washington.

\section{Saisettia oleae Bern.}

Reh, Dr. L. : Zeitschr. f. Entom. VIII, pp. 418-419. Nor. 1, 1903. Bibliography, food plants, etc.

Theobald, F. V.: 1st Rept. Ec. Ent. Br. Mus.. p. 140 (1903).

Coleman, G. A. : Journ. N. Y. Ent. Soc. XI, p. 82. June, 1903.

Coleman, G. A. : Journ. N. Y. Ent. Soc. XI, p. 74. June, 1903.

King, G. B. : Ent. News, XIV, p. 205. June, 1903.

Thro. W. C. : Bull. 209. Cornell Univ. Agr. Exp. St., p. 214, pl. IV; figs. 1-3 ; pl. Y. fig. 8, Jan. 1903.

Ehrhorn, E. M. : 1st Bien. Rept. of Com. Hort. Sta. Cal. 1903-04. p. 111.

Stiftz, A.: Jahr. d. Pflanz. (1904.) p. 137.

Kirkaldy, G. W. : The Entomologist, vol. XXXVII, Sept. 1904, p. 22 S.

Green. E. E.: The Coccidæ of Ceylon. Part III, p. 227 (1904).

On Antidesma bunius, Grewia orientalis, Duranta, Thespesia populnea, Cajanus indicus.

Dickel, Dr. O.: Zeit. f. wiss. Insekt. Heft II. Bd. I, Nov. 20, 1905, p. 447.

Simpson, C. B. : Transvaal Dept. Agric. Ann. Rept. of Director. 1904-1905, p. 350.

Cockerell, T. D. A. : Proc. Davenport Acad. Sciences, vol. X, 1905.

Del Guercio: Boll. Uff. del Min. d'Agr. Indust. \& Comm. V. 3, p. 262 (1906).

Records Tomocera californica, Coccophagus sp. and Scutellista cyanea as parasites.

Tyrrell, Mary W.: Rep. Agr. Exp. Sta. of the Univ. Cal. Year 1894-95, p. 265. Plates II, III, IV.

Herrera, A. L. : Bol. d. l. Com. de Parasitologia Agric. Tomo III. num. I (1906).

Ehrhorn, E. M.: The Can. Entom. Vol. XXXVIII, No. 10, Oct. 1906, p. 332.

Gahan, A. B. : Bull. 119 Md. Ag. Exp. Sta. July, 1907, pp. 11-12, fig. 4.

Ehrhorn, E. M. : 2d Bien. Rep. Com. of Hort. Sta. of Cal. 1905-06. pp. 23 and 223.

Carnes, E. K. : 2d Bien. Rep. Com. Hort. Sta. Cal. 1905-06 (1907), pp. 193-194.

Paoli. Berlese An. \& Am.: "Redia," vol. IV, Fasc. I, pp. 48-80. 4 figs. (07.) Figures illustrating various stages of $L$. oleae, as well as those of its predaceous and parasitic enemies.

Green. E. E. : Trans. Linn. Soc. of London. Vol. XII, part 2, Dec. 1907, p. 200.

Reported from Chagos Is., Aldabia, Mauritius, Europe, N. Z., Australia, China, Japan, Java, H. I., S. Africa, Ceylon, Brazil, W. Indies, Mexico, U. S. A.

Newman, L. J.: Jn. Dep. Ag. of Western Australia. Vol. XV, part 12. Dec. 1907. p. 914.

"Reduced to a harmless scale in this state by its introduced natural enemies."

Froggatt, W. W.: "Australian Insects" (1907), p. 376.

Autran, E. : Bol. del Min. di Agr. Vol. VII, No. 8, p. 151, 1907.

Howard, C. W. : Transvaal Ag. Jn. Vol. VI, No. 22, Jan. 190S, p. 274.

Froggatt, W. W. : The Jn. of Agr. of Victoria. Vol. VI, pt. 5,8 th May, 1908, p. 277.

Lea, A. : Insect and Fungus Pest of Orchard and Farm, Tasmania, 3d edition, p. 64. (1908.)

Pease, S. A. : 34th Fruit Growers' Convention Sta. of Cal. (1908.) p. 40.

Lounsbury, C. P.: Rep. of Gov. Ent. Year 1907. Cape of Good Hope, Dep. Agr. Cape Town. 1908.

Cook, A. J.: Off. Rep. 34th Fruit Grow. Con. of Cal. p. 50. Sacramento. 1908.

Ehrhorn. E. II. : Proc. of 33d Fruit Grow. Con. of Cal. p. 151. (1908.) 
Cook, M. T.: Bull. No. 9. Estacion Central Agron. de Cuba. Feb. 1908. p. 26. fig. 34 .

Froggatt, W. W. : The Jn. Dept. of Ag. of So. Australia. Vol. XII. No. 1. Aug. 1908. p. 38.

Martinelli, Dr. G.: Bol. di Lab. di Zool. Generale e Agraria. Vol. II (1908) pp. 217-20.

Descr. fig. hosts and parasites.

Newman, L. J.: Jn. Dept. of Ag. W. Australia. Dec. 1908. Vol. XVII, p. 942.

Cook, M. T., \& Horne, W. T.: Bull. No. 9. Estacion Central Agron. de Cuba. Feb. 1908. p. 26 . fig. 34 .

Lindinger, L. : Zeit, f. wiss. Insektenbiol., v. 5, p. 224 (1909).

Essig, O. E. : Pomona Jn. of Entom. Vol. 1, No. 1. March, 1909. pp. 12-15. fig. 9. Carnes, E. K. : 3d Bien. Rept. Com. Hort. Cal. p. 25. (1909.)

Dean, Geo. A. : Trans. Kans. Acad. of Sciences. Vol. XXII. p. 269. (1909.)

Sanders, J. G. : Jn. Econ. Ent. Vol. II. No. 6. p. 440. pl. 20. fig. 2. Dec. 1909.

Severin, H. C., \& H. H. P.: Jn. Econ. Ent. Vol. II. No. 4. p. 297. Aug. 1909.

Newman, L. J. : Jn. Dept. Agr. W. A. XVIII, 7, p. 500 (1909). Fig.

Fullaway, D. T. : Hawaii Agr. Exp. Sta. Bul. 18. p. 16. (1909.)

Pestana, C.: Bull. Agricole de l'Algierie et de la Tunisie, No. 6, 15, March, 1909. pp. $146-48$.

Brick, C. : Sta. fur Pflanzenschutz zu Hamburg, X, p. 11. (1909.)

Garcia, N.: Bol. Agr. Tech. y Econ. 1, No. 3, p. 268. (1909.)

Rrick, C. : Sta. fur Pflanzenschutz zu Hamburg, XI, p. 6. (1909.)

Kirk, T. W., \& Cockayne, A. H. : Ann. Rep. Dept. Agr. Div. Biol. \& Hort. p. 285. (1909.)

Doane, W. R. : Can. Ent., xli, 8, p. 297. (1909.)

Barber, T. C.: Jn. Econ. Entom. Vol. 3, No. 5, p. 424. Oct. 1910.

Knischewky: Zeit. fur Pflanzenkrankheiten, Band XX, Heft. 5, p. 267. (1910.) 
REPORTS.

1896. Report of the Viticultural Work during the seasons 1887-93, with data regarding the Vintages of 1894-95.

1897. Resistant Vines, their Selection, Adaptation, and Grafting. Appendix to Viticultural Report for 1896.

1902. Report of the Agricultural Experiment Station for 1898-1901.

1903. Report of the Agricultural Experiment Station for 1901-03.

1904. Twenty-second Report of the Agricultural Experiment Station for 1903-04.

\section{BULLETINS.}

Reprint. Endurance of Drought in Soils of No. 190. The Brown Rot of the Lemon. the Arid Region.

No. 128. Nature, Value, and Utilization of Alkali Lands, and Tolerance of Alkali. (Revised and Reprint, 1905.)

133. Tolerance of Alkali by Various Cultures.

147. Culture Work of the Sub-stations.

149. California Sugar Industry.

151. Arsenical Insecticides.

152. Fumigation Dosage.

153. Spraying with Distillates.

159. Contribution to the Study of Fermentation.

162. Commercial Fertilizers. (Dec. 1, 1904.)

165. Asparagus and Asparagus Rust in California.

167. Manufacture of Dry Wines in Hot Countries.

168. Observations on Some Vine Diseases in Sonoma County.

169. Tolerance of the Sugar Beet for Alkali.

170. Studies in Grasshopper Control.

171. Commercial Fertilizers. (June $30,1905$.

172. Further Experience in Asparagus Rust Control.

174. A New Wine-cooling Machine.

176. Sugar Beets in the San Joaquin Valley.

177. A New Method of Making Dry Red Wine.

178. Mosquito Control.

179. Commercial Fertilizers. (June, 1906.)

180. Resistant Vineyards.

181. The Selection of Seed-Wheat.

182. Analysis of Paris Green and Lead Arsenic. Proposed Insecticide Law.

183. The California Tussock-moth.

184. Report of the Plant Pathologist to July 1, 1906.

185. Report of Progress in Cereal Investigations.

186. The Oidium of the Vine.

187. Commercial Fertilizers. (January, 1907.)

188. Lining of Ditches and Reservoirs to Prevent Seepage and Losses.

189. Commercial Fertilizers. (June, 1907.)

191. California Peach Blight.

192. Insects Injurious to the Vine in California.

193. The Best Wine Grapes for California; Pruning Young Vines; Pruning the Sultanina.

194. Commercial Fertilizers. (Dec., 1907.)

195. The California Grape Root-worm.

197. Grape Culture in California; Improved Methods of Wine-making; Yeast from California Grapes.

198. The Grape Leaf-Hopper.

199. Bovine Tuberculosis.

200. Gum Diseases of Citrus Trees in California.

201. Commercial Fertilizers. (June, 1908.)

202. Commercial Fertilizers. (December, 1908.)

203. Report of the Plant Pathologist to July 1, 1909.

204. The Dairy Cow's Record and the Stable.

205. Commercial Fertilizers. (December, 1909.)

206. Commercial Fertilizers. (June, 1910.)

207. The Control of the Argentine Ant.

208. The Late Blight of Celery.

209. The Cream Supply.

210. Imperial Valley Settlers' Crop Manual.

211. How to Increase the Yield of Wheat in California.

212. California White Wheats.

213. The Principles of Wine-making.

214. Citrus Fruit Insects.

215. The House Fly in its Relation to Public Health.

216. A Progress Report upon Soil and Climatic Factors Influencing the Composition of Wheat.

217. Honey Plants of California.

218. California Plant Diseases.

219. Report of Live Stock Conditions in Imperial County, California.

220. Fumigation Studies No. 5 ; Dosage Tables.

221. Commercial Fertilizers. (October, 1911.)

222. The Red or Orange Scale. 


\section{CIRCULARS.}

No. 1. Texas Fever.

5. Contagious Abortion in Cows.

7. Remedies for Insects.

9. Asparagus Rust.

11. Fumigation Practice.

12. Silk Culture.

15. Recent Problems in Agriculture. What a University Farm is For

19. Disinfection of Stables.

29. Preliminary Announcement Concerning Instruction in Practical Agriculture upon the University Farm, Davis, Cal.

30. White Fly in California.

32. White Fly Eradication.

33. Packing Prunes in Cans. Cane Sugar vs. Beet Sugar.

36. Analyses of Fertilizers for Consumers.

39. Instruction in Practical Agriculture at the University Farm.

46. Suggestions for Garden Work in California Schools.

48. Butter Scoring Contest, 1909.

49. Insecticides.

50. Fumigation Scheduling.
No. 52. Information for Students Concerning the College of Agriculture.

54. Some Creamery Problems and Tests.

55. Farmers' Institutes and University Extension in Agriculture.

58. Experiments with Plants and Soils in Laboratory, Garden, and Field.

59. Tree Growing in the Public Schools.

60. Butter Scoring Contest, 1910.

61. University Farm School.

62. The School Garden in the Course of Study.

63. How to Make an Observation Hive.

64. Announcement of Farmers' Short Courses for 1911.

65. The California Insecticide Law.

66. Insecticides and Insect Control.

67. Development of Secondary School Agriculture in California.

68. The Prevention of Hog Cholera.

69. The Extermination of MorningGlory.

70. Observations on the Status of Corn Growing in California 